\title{
Monetary policy rules in emerging countries: Is there an augmented nonlinear taylor rule? ${ }^{\text {is }}$
}

\author{
Guglielmo Maria Caporale ${ }^{\mathrm{a}, *}$, Mohamad Husam Helmi ${ }^{\mathrm{b}}$, Abdurrahman Nazif Çatık ${ }^{\mathrm{c}}$, \\ Faek Menla Ali ${ }^{\mathrm{d}}$, Coşkun Akdeniz ${ }^{\mathrm{e}}$ \\ ${ }^{a}$ Department of Economics and Finance, Brunel University London, UK \\ ${ }^{\mathrm{b}}$ Durham Business School, University of Durham, UK \\ ${ }^{\mathrm{c}}$ Department of Economics, Ege University, Turkey \\ ${ }^{\mathrm{d}}$ School of Business Management and Economics, University of Sussex, Brighton BN1 9SL, UK \\ ${ }^{\mathrm{e}}$ Department of Economics, Namik Kemal University, Turkey
}

\section{A R T I C L E I N F O}

JEL classification:

C13

C51

C52

E52

E58

Keywords:

Emerging countries

Nonlinearities

Taylor rule

\begin{abstract}
A B S T R A C T
This paper examines the Taylor rule in five emerging economies, namely Indonesia, Israel, South Korea, Thailand, and Turkey. In particular, it investigates whether monetary policy in these countries can be more accurately described by (i) an augmented rule including the exchange rate, as well as (ii) a nonlinear threshold specification (estimated using GMM), instead of a baseline linear rule. The results suggest that the reaction of monetary authorities to deviations from target of either the inflation or the output gap differs in terms of the size and/or statistical significance of the coefficients in the high and low inflation regimes in all countries. In particular, the exchange rate has an impact in the former but not in the latter regime. Overall, an augmented nonlinear Taylor rule appears to capture more accurately the behaviour of monetary authorities in these countries.
\end{abstract}

\section{Introduction}

The low level of inflation achieved in recent decades in the developed world is often seen as the result of the adoption of policy rules by independent central banks. Taylor (1993) showed how monetary policy in the US during the 1980s and the early 1990s could indeed be described in terms of a clearly specified rule. Later studies (e.g., Clarida et al., 1998; Svensson, 1999; Taylor, 1999; Ball, 2000; Shortland and Stasavage, 2004; Ghatak and Moore, 2011) extended the original linear Taylor rule and emphasised possible nonlinearities in the reaction function of central banks (e.g., Taylor and Davradakis, 2006; Martin and Milas, 2013; Caglayan et al., 2016). These can arise either from nonlinear macroeconomic relationships (see Robert-Nobay and Peel, 2003; Dolado et al., 2005, among others) or from asymmetric preferences or objectives of policymakers (see Favero et al., 2000; Taylor and Davradakis, 2006; Surico, 2007; Cukierman and Muscatelli, 2008; Castro, 2011; Martin and Milas, 2004, 2013; Ahmad, 2016).

Several recent empirical studies have provided evidence of nonlinearities and threshold effects in the reaction of monetary authorities to inflation and output gaps (see Favero et al., 2000, Taylor and Davradakis, 2006; Surico, 2007; Cukierman and Muscatelli, 2008; Castro, 2011; Martin and Milas, 2004, 2013; Ahmad, 2016, among others). However, only a few papers have addressed this issue in the case of developing and emerging economies (see Hasanov and Omay, 2008; Akyürek et al., 2011; Miles and Schreyer, 2012; Akdoğan, 2015; Holtemöller and Mallick, 2016).

The present study aims to fill this gap in the literature by estimating a threshold nonlinear Taylor rule in five inflation targeting (IT) emerging countries (Indonesia, Israel, Korea, Thailand, and Turkey); moreover, an augmented rule including the exchange rate is considered. Markov regime switching models have often been estimated to capture nonlinearities in monetary policy rules (Bae et al., 2012; Murray et al., 2015; Gonzalez-Astudillo, 2014). However, these have been criticised for not allowing a smooth transition between regimes (Castro, 2011), unlike Threshold Autoregressive (TAR) and Smooth Transition Autoregressive (STAR) models in which the regime change is driven by past values of the

\footnotetext{
We would like to thank the Editor (Professor Sushanta Mallick) and two anonymous referees for their useful comments and suggestions on an earlier draft of this manuscript. * Corresponding author. Department of Economics and Finance, Brunel University London, UB8 3PH, UK.

E-mail address: Guglielmo-Maria.Caporale@brunel.ac.uk (G.M. Caporale).
} 
variables in the sample (Tong, 1990; Akdogan, 2015).

Therefore in this paper we estimate a TAR specification which is ideally suited to capturing asymmetries in the behaviour of monetary policy authorities, unlike Markov regime switching models that treat regime changes as exogenous (since they are driven by an unobservable state variable - Atanasova, 2003; Balke, 2000; Castro, 2011). Moreover, this model allows to estimate the optimal threshold value of inflation in each country. The estimation method is the generalised method of moments (GMM), which has the advantage of taking into account the possible correlation between the regressors and the error term that could give rise to endogeneity problems.

The layout of the paper is as follows. Section 2 reviews the literature on the Taylor rule. Section 3 outlines the econometric model and discusses the data. Section 4 presents the empirical results. Section 5 offers some concluding remarks.

\section{Literature review}

Since the 1990s, several central banks around the world have adopted an inflation targeting framework (Bernanke and Mishkin, 1997). This is thought to have several advantages, namely: (1) to lead to more independent central banks; (2) to reduce inflation, making monetary policy more credible; (3) to decrease uncertainty about the expected level of inflation; and (4) to improve communication between policy-makers and the public, making monetary policy more transparent (Bernanke and Mishkin, 1997; Svensson, 2000; Gemayel et al., 2011). However, under this framework a lower inflation rate might be achieved at the cost of lower output and higher unemployment in comparison to other monetary regimes (Bernanke and Mishkin, 1997).

Taylor $(1993,1999)$ argued that the monetary policy of the Fed can broadly be described by an interest rate rule based on the deviations of output and inflation from target (see also Orphanides, 2002). The adoption of such a rule appears to have had a significant impact on economic performance in the US (Bernanke, 2004; Siegfried, 2010; Taylor, 2013a). Clarida et al. (1998) investigated the so-called Taylor rule in two sets of countries, i.e., the G3 (Germany, Japan and the USA) and the E3 (UK, France and Italy). They found that monetary authorities in the G3 adjusted the real interest rate in response to inflationary pressures following a forward-looking rather than a backward-looking rule, whilst in the E3 other central banks followed the German Bundesbank very closely. Gerlach and Schnabel (2000) concluded that monetary policy in the Economic and Monetary Union (EMU) area was well described by a Taylor rule, and Stuart (1996) reached the same conclusion for the UK. Côté et al. (2004) reported that none of their estimated seven simple Taylor rules for the Canadian economy was robust to model uncertainty.

Svensson (2003) argued that central banks should announce and follow a simple instrument rule (see also Judd and Rudebusch, 1998; McCallum, 1999; Taylor, 2000; Rudebusch, 2002). However, a number of papers have criticised the Taylor rule arguing that following it mechanically is undesirable (e.g., Ball, 2000; Svensson, 1999, 2003; McCallum and Nelson, 1999; Carlson, 2007; and Martin and Milas, 2013, among others). For example, the Federal Reserve cut the interest rate sharply during the stock market crash in 1987, the Asian crisis in 1997-98 (Carlson, 2007) and the recent global financial crisis. Similarly, the Bank of England reduced the interest rate from 5\% in 2008 to $0.5 \%$ in March 2009 - the biggest cut since its creation in 1694 (Astley et al., 2009). Policy makers might need to adjust the rule when new information arrives (Taylor, 2000; Woodford, 2001). For instance, Martin and Milas (2013) pointed out that the Bank of England abandoned its monetary rule during the recent financial crisis with the aim of achieving financial stability. Taylor (2013b) suggested that deviations from the Taylor rule might be due to international spillovers.

Other issues raised in the literature include the accurate estimation of potential output (MacCallum and Nelson, 1999) and data uncertainty with real time as opposed to ex-post data (Orphanides and Van Norden,
2002; Hatipoglu and Alper, 2008). Under-forecasting or over-forecasting the output gap might lead to inappropriate policy actions (Orphanides, 2002). The Hodrick-Prescott (HP) filter is the most commonly used method because of its flexibility (Cerra and Saxena, 2000), but it has various disadvantages. The first is that the most recent observations suffer from a lack of accuracy (Shortland and Stasavage, 2004). The second is the possibility of misspecification of the underlying economic structure since the suggested values of the filter are specific to US data (Sarikaya et al., 2005). The third is the fact that output is more volatile in the case of the emerging economies; therefore, the estimation of trend output suffers from wider variation (Hatipoglu and Alper, 2008).

Another criticism of the baseline Taylor rule is that it does not allow the central bank to smooth interest rate movements (Goodfriend, 1991), whilst a smoothing parameter in the reaction function might be important to achieve credibility as well as to avoid any capital market disruption (McCallum, 1999; Levin et al., 1999 and Clarida et al., 2000, among others).

\subsection{The augmented Taylor rule}

The baseline Taylor rule might also be inappropriate for open economies subject to external shocks (Svensson, 2000, 2003); in this case it might be necessary instead to include other variables such as the exchange rate (see, Ball, 2000; Svensson, 2000, 2003; Obstfeld and Rogoff, 2000; Leitemo and Söderström, 2005; Ostry et al., 2012; Galimberti, and Moura, 2013, Ghosh et al., 2016, among others). Taylor (2001), Edwards (2007) and Mishkin (2007) conclude that this is in fact not required in the case of the developed economies; however, it might be in the emerging countries.

Ball (1999) had shown that following a monetary policy rule including the exchange rate instead of the original Taylor rule results in a lower variance of the consumer price index (CPI). Debelle (1999) also argued that the unpredictability of output and inflation is reduced in this way. Ball (1999) concluded that such an augmented rule was followed in Canada from 1975 to 2003, whilst Lubik and Schorfheide (2007) found that it was in the UK as well as Canada, but not in Australia and New Zealand. Moreover, Taylor (2000) argued that a flexible exchange rate combined with a policy rule based on inflation targeting is the only sound monetary policy for developing and emerging economies. A floating exchange regime was instrumental to achieving low and stable inflation in such countries according to Masson et al. (1997). However, this conventional wisdom is increasingly being questioned (Ghosh et al., 2016). The exchange rate pass-through can be significant and should also be considered (Svensson, 2000; Goldberg and Campa, 2010): it may force central banks targeting price stability to tighten their monetary policy, or lead to a competitiveness loss (Gagnon and Ihrig, 2004; Baily, 2003; Bailliu and Fujii, 2004; Ghosh et al., 2016).

In addition, Daude et al. (2016) pointed out that central banks in emerging markets with a flexible exchange rate regime frequently intervene in their foreign exchange market: they have an implicit comfort zone for smoothing exchange rate fluctuations, even if they do not specify an exchange rate target (see also Ghosh et al., 2016; de la Torre et al., 2013; Mohanty, 2013). Gali and Monacelli (2005), Adolfson et al. (2008), and Caglayan et al. (2016) also found that the behaviour of central banks is affected by exchange rate movements using dynamic stochastic general equilibrium (DSGE) models. Garcia et al. (2011) concluded that including the exchange rate in the linear Taylor rule does not provide any significant gain for developed countries, but it does in the case of emerging economies. Shortland and Stasavage (2004) showed that the central bank for West African Economic and Monetary Union (BCEAO) considered the foreign exchange position in addition to the inflation rate and the output gap in setting its monetary policy rule. Filosa (2001) also reported that central banks reacted strongly to exchange rate movements in Indonesia, Korea, Malaysia, Thailand, Brazil, Chile and Mexico. Further, Mallick and Sousa (2012) estimated a B-SVAR model including the exchange rate and found that the domestic currency 
appreciates for four quarters following an interest rate shock; in addition, the intervention of the central bank in the forex market reduces the degree of persistence in the appreciation of the exchange rate.

Mohanty and Klau (2005) and Aizenman et al. (2011) provided further evidence that central banks in emerging economies with IT (implicitly) take into account exchange rate movements in the conduct of monetary policy. Some authors (e.g., Calvo and Reinhart, 2002; Galimberti and Moura, 2013; Catalán-Herrera, 2016) argue that the adoption of IT in the emerging countries does not stop them from intervening in the foreign exchange market (for instance, in the case of Israel - see Brenner and Sokoler, 2010). Yilmazkuday (2008) found that the central bank of Hungary only reacts to exchange rate movements, while those of Poland and the Czech Republic seem to respond to deviations of output and inflation from their targets in setting their interest rate. Further, Granville and Mallick (2010) argued that the Bank of Russia failed to achieve sustained low inflation because of its exchange rate targeting policy.

Finally, Shrestha and Semmler (2015) estimated a simple linear Taylor rule using an autoregressive distributed lag (ARDL) model in five East Asian countries (Malaysia, Korea, Thailand, Indonesia and Philippines), and concluded that the baseline Taylor rule is not sufficient to describe monetary policy in emerging countries and should be amended to take into account financial instability. More recently, Ghosh et al. (2016) also provided evidence of foreign exchange intervention which is consistent with achieving price stability under inflation targeting in the emerging countries.

\subsection{The nonlinear Taylor rule}

A further important issue is whether the reaction function of central banks might be characterised by nonlinearities reflecting either the structure of the economy (Robert-Nobay and Peel, 2003; Dolado et al., 2005, among others) or their own asymmetric preferences (see, Favero et al., 2000, Taylor and Davradakis, 2006; Surico, 2007; Cukierman and Muscatelli, 2008; Castro, 2011; Martin and Milas, 2004, 2013). For instance, policy responses might be different depending on the phase of the cycle, with output stabilisation being given more importance during recessions and inflation being instead the main concern during expansions (Cukierman and Gerlach, 2003; Ahmad, 2016). Dolado et al. (2000) found that the central banks of Spain, France and Germany are less responsive to inflation when it is below as opposed to above target. Taylor and Davradakis (2006) suggested that the Bank of England sets interest rates following a nonlinear Taylor rule, despite its symmetric inflation target. Martin and Milas (2013) also found empirical support for a nonlinear Taylor rule in the UK during the recent financial crisis.

However, much less evidence on nonlinear Taylor rules is available for the developing and emerging countries. Moura and de Carvalho (2010) examined the conduct of monetary policy in seven Latin American countries. Their findings suggest asymmetric responses to inflation, output and exchange rate in Brazil, Chile and Mexico. Hasanov and Omay (2008) investigated possible asymmetries over the business cycles using monthly data spanning the period 1990:01-2000:10. They estimated a threshold Taylor rule using GMM where the output gap is the transition variable, and found that the Central Bank of Turkey reacts more strongly to output movements during recessions than expansions. Moreover, it responds to foreign reserves, real exchange rates and short-term capital inflows both in expansion and recession periods, and to money growth, budget deficits, and net foreign assets only in expansion periods. Akyürek et al. (2011) also examined inflation targeting in Turkey by estimating both linear and nonlinear Taylor rules (using a rolling method for the latter) over the period 1999:07-2008:07; they found that a Taylor rule

\footnotetext{
1 Their sample includes five key emerging market economies: Brazil, Russia, India, China, and South Africa.
}

including the foreign interest rate and the exchange rate captures accurately the monetary policy of the Central Bank of Turkey.

Miles and Schreyer (2012), on the other hand, examined the reaction functions of the central banks of four Asian countries, namely Thailand, Malaysia, Korea and Indonesia using quantile regression analysis. They found evidence of nonlinearities but some cross-country differences. For instance, monetary authorities in Indonesia do not respond to the output gap in the lower quantiles ( 0.2 and 0.4$)$, while the central bank of Korea responds to it in both the lower and higher quantiles. Further, only the central banks of Malaysia and Indonesia react to exchange rate fluctuations. Jawadi et al. (2014) estimated a smooth transition regression (STR) model to test for nonlinearity of monetary policy rules in China and Brazil. They found that the real effective exchange rate is one of the major drivers of the adjustments in the interest rate in both countries. Finally, Akdoğan (2015) found evidence of asymmetric behaviour of monetary policy in nineteen inflation-targeting countries including Thailand, Turkey and Israel using an Asymmetric Exponential Smooth Transition Autoregressive (AESTAR) model. The estimated nonlinear Taylor rule was found to predict well out of sample.

\section{Methodology and data}

\subsection{The linear Taylor rule}

Taylor (1993) suggested the following monetary policy rule for the US Fed:

$r_{t}=p_{t}+0.5 y_{t}+0.5\left(p_{t}-2\right)+2$,

where $r_{t}$ is the Federal funds rate, $p_{t}$ is the rate of inflation over the previous four quarters and $y_{t}$ is the percentage deviation of real GDP from target. This implies that the policy interest rate goes up if inflation increases above the $2 \%$ target or if real GDP rises above trend GDP. Taylor (1998) modified this rule by adding two extra variables, namely the central bank's target inflation rate $\left(\pi^{*}\right)$ and estimate of the equilibrium real rate of interest $\left(r_{t}^{f}\right)$ as shown below:

$r_{t}=\pi_{t}+g y_{t}+h\left(\pi_{t}-\pi^{*}\right)+r_{t}^{f}$,

where $\pi_{t}$ is the inflation rate. This simple formulation has been criticised for not taking into account the effects of the exchange rate on monetary policy, which have been considered by later studies, e.g., Ball (1999), Svensson (2000), Taylor (1999) and Ghosh et al. (2016). The augmented Taylor rule can be written as:

$i_{t}=f \pi_{t}+g y_{t}+h_{0} e_{t}+h_{1} e_{t-1}$,

where $i_{t}$ is the short-term nominal interest rate and $e_{t}$ is the real exchange rate. No intercept in this equation implies that the targeted inflation rate is zero and interest rates and exchange rates are measured relative to their long-run values (Taylor, 2001).

In the present study, we first estimate the following linear Taylor rule using GMM as in Clarida et al. (1998, 2000),

$$
\begin{aligned}
r_{t}= & \alpha_{0}+\alpha_{1} r_{t-1}+\alpha_{2} \sum_{k=1}^{3}\left(E_{t-1} \pi_{t+k}-\pi^{t}\right)+\alpha_{3} \sum_{k=1}^{3}\left(E_{t-1} y_{t+k}\right) \\
& +\alpha_{4} \sum_{k=1}^{3}\left(E_{t-1} \text { rer }_{t+k}\right)+\varepsilon_{t},
\end{aligned}
$$

where $r_{t}$ is the short-term interest rate, $\pi_{t+k}$ is the CPI inflation, $\pi^{t}$ is the inflation target and $y_{t+k}$ is the output gap calculated as the difference between the log of output from its potential, and $\mathbf{r e r}_{t+k}$ is real effective exchange rate. It is assumed that policy makers respond to forecasts of inflation, the output gap and the exchange rate over the coming quarter, therefore a 3-month lead average is used for these variables in the estimation (Svensson, 1997; Martin and Milas, 2013; Ahmad, 2016). 


\subsection{The nonlinear Taylor rule}

Given the mounting evidence of possible nonlinearities in the reaction function of central banks, we also estimate a threshold model specified as follows (see following Taylor and Davradakis, 2006; Martin and Milas, 2013; Caglayan et al., 2016): regime, and have similar development levels. A detailed description of the variables used is given in Table A1 in Appendix A. Output is proxied by the industrial production index (IPI) except in the case of Indonesia, where this series is not available and the manufacturing index is used instead. The output gap, $y_{t+k}$, is calculated as the proportional deviation of the 3-month leading average of the log IPI from its Hodrick and

$$
\begin{aligned}
& r_{t}=I\left[\pi_{t-1} \geq \pi^{*}\right]\left[\beta_{0}^{H}+\beta_{1}^{H} r_{t-1}+\beta_{2}^{H} \sum_{k=1}^{3}\left(E_{t-1} \pi_{t+k}-\pi^{t}\right)+\beta_{3}^{H} \sum_{k=1}^{3}\left(E_{t-1} y_{t+k}\right)+\beta_{4}^{H} \sum_{k=1}^{3}\left(E_{t-1} \text { rer }_{t+k}\right)\right] \\
& +I\left[\pi_{t-1}<\pi^{*}\right]\left[\beta_{0}^{L}+\beta_{1}^{L} r_{t-1}+\beta_{2}^{L} \sum_{k=1}^{3}\left(E_{t-1} \pi_{t+k}-\pi^{t}\right)+\beta_{3}^{L} \sum_{k=1}^{3}\left(E_{t-1} y_{t+k}\right)+\beta_{4}^{L} \sum_{k=1}^{3}\left(E_{t-1} \text { rer } r_{t+k}\right)\right]+\varepsilon_{t} .
\end{aligned}
$$

The threshold variable is the inflation rate, since central banks might respond more aggressively when inflation overshoots than when it undershoots its target (Akdoğan, 2015); specifically, we use the first lag of inflation, $\pi_{t-1} \cdot{ }^{2} \pi^{*}$ is the optimal threshold value of inflation defining the high/low inflation regime of the model, and is estimated endogenously along with the other parameters (Martin and Milas, 2013). $I[\cdot]$ is the dummy indicator function that equals 1 when $\pi_{t-1} \geq \pi^{*}$, and 0 otherwise. Therefore, the monetary policy responses are driven by the optimal threshold value of $\pi_{t-1}$.

In the above regression, the optimal threshold value of inflation, $\pi^{*}$, is estimated along with the other parameters by minimising an appropriate criterion function using a one-dimension grid search including the possible breakpoints of inflation. Following Taylor and Davradakis (2006), we use the GMM estimator given the possible correlation between the regressors and the error term. The criterion function that the GMM minimises is given by

$J=\widehat{\varepsilon}^{\prime} Z W^{-1} Z^{\prime} \widehat{\varepsilon}^{\prime}$,

where $\widehat{\varepsilon}^{\prime}$ is the estimated disturbance vector and $\mathrm{Z}$ is a vector of $l$ instrumental variables satisfying the orthogonality condition $E\left(Z^{\prime} \varepsilon\right)=0$. This condition will generally not hold exactly in sample for estimated values of $\varepsilon$, but the GMM estimator minimises a weighted average of the squared values of the $l$ sample moments $Z^{\prime} \widehat{\varepsilon}$. In a linear context a two-step procedure can be followed to construct the weight matrix $W$ based on the centred estimates of the moment conditions (see e.g., Hansen, 2016).

For a threshold model along with the other parameters a onedimensional grid search is conducted over the interval $\Pi^{*}$ including the possible breakpoint of $\pi_{t-1}[0.10,0.90]$ :

$\widehat{\pi}^{*}=\arg \cdot \min _{\pi_{1} \in \Pi^{*}} \cdot J$

where $J$ is the function minimised by GMM, as explained in Eq. (6) (Taylor and Davradakis, 2006).

\subsection{Data}

We estimate both the linear and threshold Taylor rule using GMM in five emerging markets, namely Indonesia, Israel, South Korea, Thailand, and Turkey, all of which have adopted IT and a floating exchange rate

\footnotetext{
${ }^{2}$ We also consider from zero to two lags of inflation as possible alternative threshold variables. The most significant threshold effect (associated with the highest value of chi-squared statistics of the threshold nonlinearity test) is obtained when the models are estimated with the first lag of inflation. The results of the test are available upon request from the corresponding author.
}

Prescott (1997) trend. ${ }^{3}$ The CPI is used to calculate the inflation rate, $\pi_{t-1}$, and its 3-month leading average, $\pi_{t+k}$; the inflation gap is constructed as the difference between $\pi_{t+k}$ and the inflation rate target, $\pi^{t}$. Further, the real effective exchange rate, $\mathrm{rer}_{t+k}$, is the 3-month leading average of the natural log of the real effective exchange rate. These data were retrieved from the IMF's International Financial Statistics (IFS) while the inflation target, $\pi^{t}$, is obtained from the websites of the central banks of the countries under investigation. All series are seasonally adjusted. The frequency is monthly and the sample period corresponds to the actual adoption of inflation targeting by the five countries examined: January 2001-November 2014 for Indonesia; June 1997-Feb 2015 for Israel; January 1998-March 2015 for South Korea; May 2000-September 2015 for Thailand; and January 2006-2015 September for Turkey.

Figs. 1-4 contain plots of the variables. Changes in policy rates are evident in all countries in our sample. There are also noticeable deviations of inflation and output from target, with low volatility of inflation gap in Turkey over the recent years; the real effective exchange rate is highly volatile in all countries, but considerably less in South Korea since the recent financial crisis.

To examine the stochastic properties of the series under consideration, a battery of standard and nonlinear unit root tests were carried out. The ADF (Dickey and Fuller, 1981), PP (Phillips and Perron, 1988), and KPSS (Kwiatkowski et al., 1992) test results (see Table 1) imply that all variables are stationary in levels, except the policy rate in Indonesia, Israel and Thailand and the real effective exchange rate in Israel and Thailand. The order of integration of interest rates, in particular, is a contentious issue. Nelson and Plosser (1982) characterised them as a nonstationary variable. Although Clarida et al. (2000) could not reject the unit root null for the nominal interest rate, they pointed out that such a variable should be considered stationary according to many theoretical models. Martin and Milas (2004, 2013) and Castro (2011) found that the order of integration of both interest rates and inflation is ambiguous, but decided to treat them as stationary, as we do in the current paper as well.

Visual inspection of the series (see Figs. 1-4) suggests that structural breaks might have occurred; for example, the recent financial crisis of 2007-8 appears to have had a significant impact on the policy rates (see Fig. 1) as well as the real effective exchange rates (see Fig. 3). As shown by Perron (1989), structural breaks reduce the power of standard unit root tests. Therefore, we also performed two unit root tests allowing for up to $m$ unknown breaks, namely the Lumsdaine and Papell (1997)

\footnotetext{
${ }^{3}$ Although the HP filter has some disadvantages, we have chosen it because of its flexibility in tracking trend output (Konuki, 2010) and followed Ravn and Uhlig (2002) in setting the adjustment parameter equal to 14400 .
} 

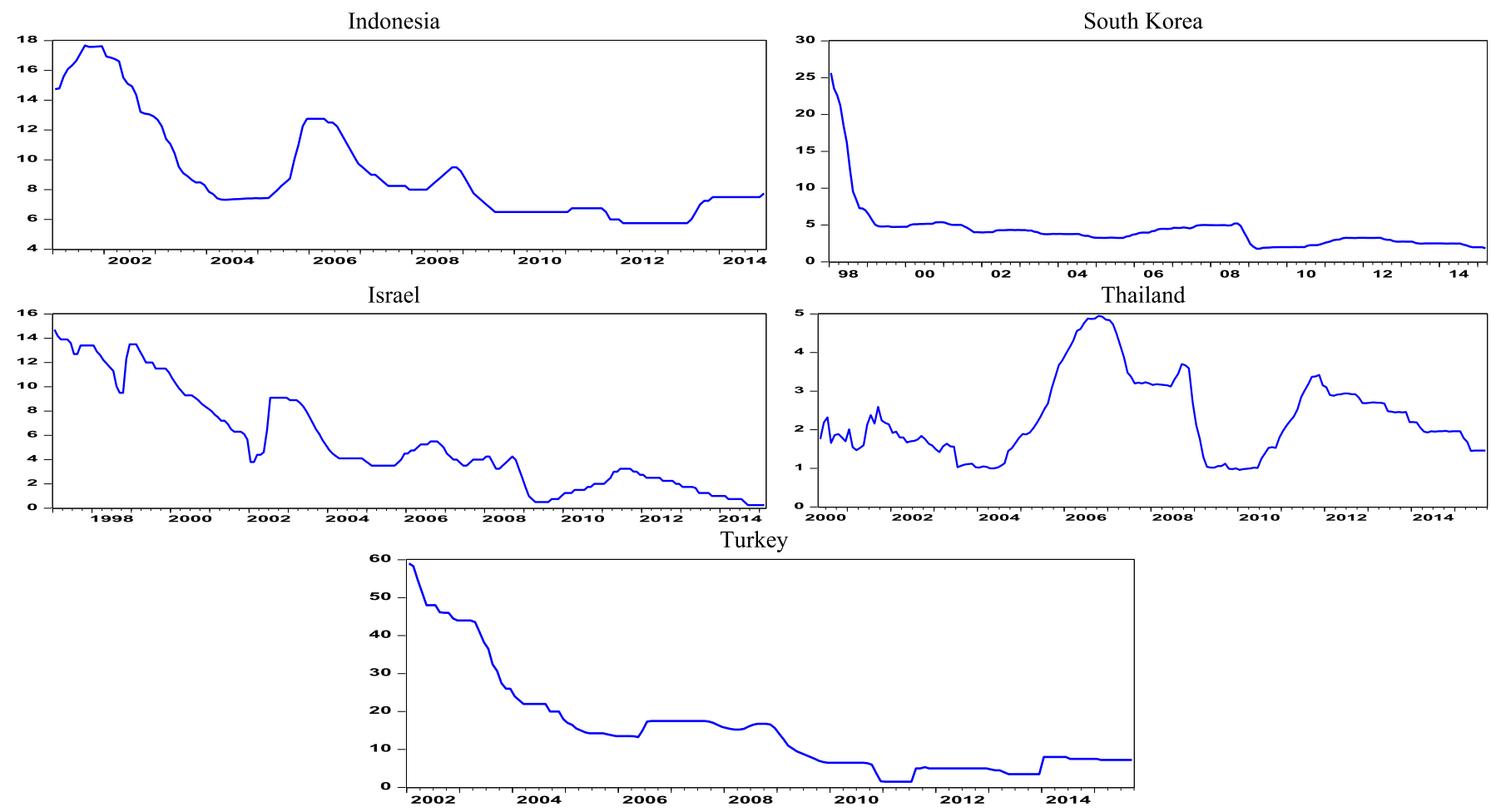

Fig. 1. The evolution of policy rates.
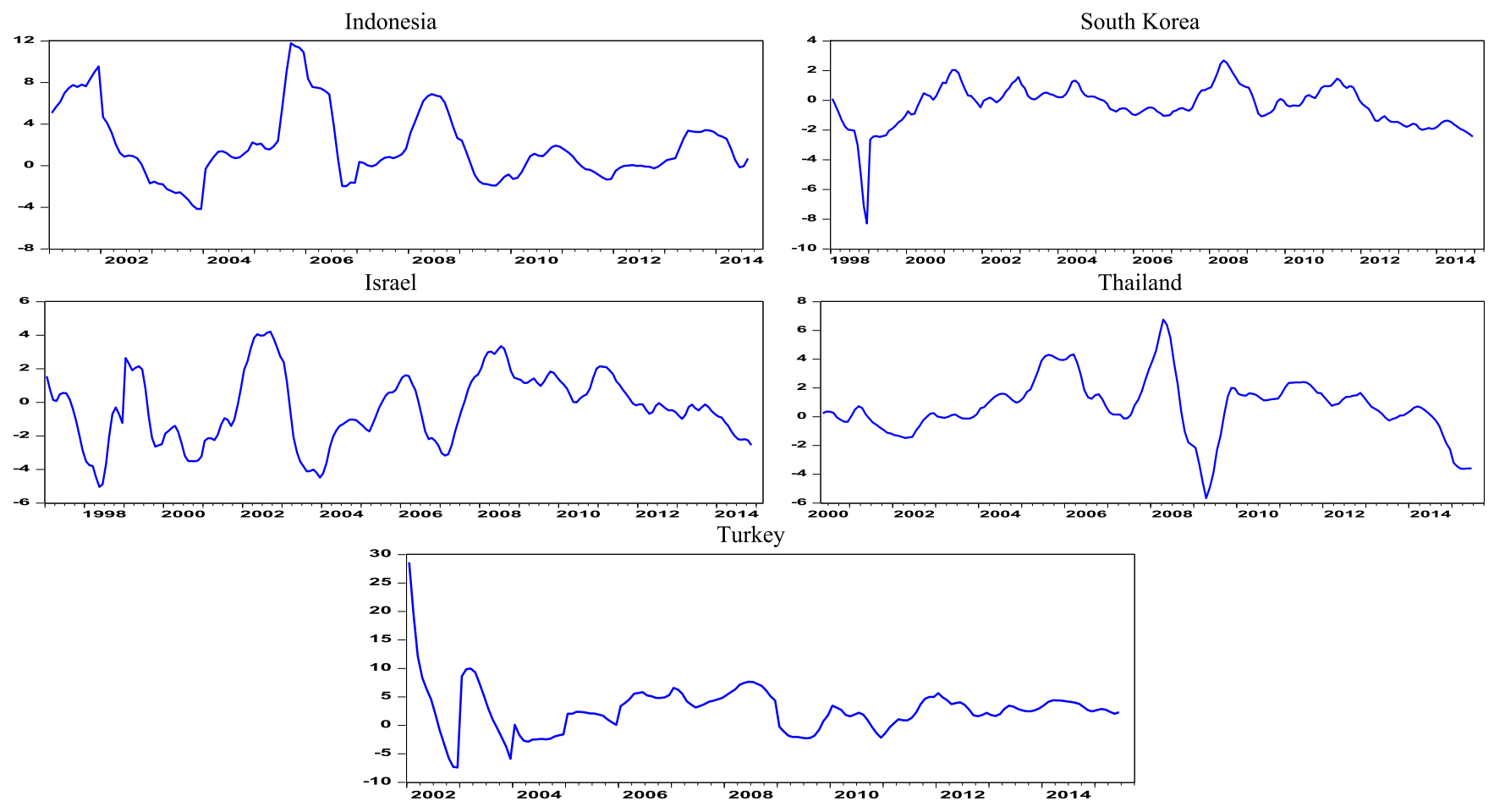

Fig. 2. The evolution of inflation gaps.

(thereafter LP) and Lee and Strazicich (2003) (thereafter LS) ones. ${ }^{4}$ At least one of these two tests (see Table 2) rejects the null hypothesis of a

\footnotetext{
${ }^{4}$ By contrast, the tests of Perron (1989), Zivot and Andrews (1992) and Banerjee et al. (1992) only allow for a single break.
}

unit root, for the series found nonstationary using the standard unit root tests, at either the $5 \%$ or the $10 \%$ level. The break dates mainly correspond to the 2001 dot-com bubble crash in the US and the 2007-8 recent global financial crisis (see Table 2). Therefore, on the basis of the standard and nonlinear unit root tests, all variables can be treated as $\mathrm{I}(0)$ and are entered into the threshold Taylor rule model in levels. 

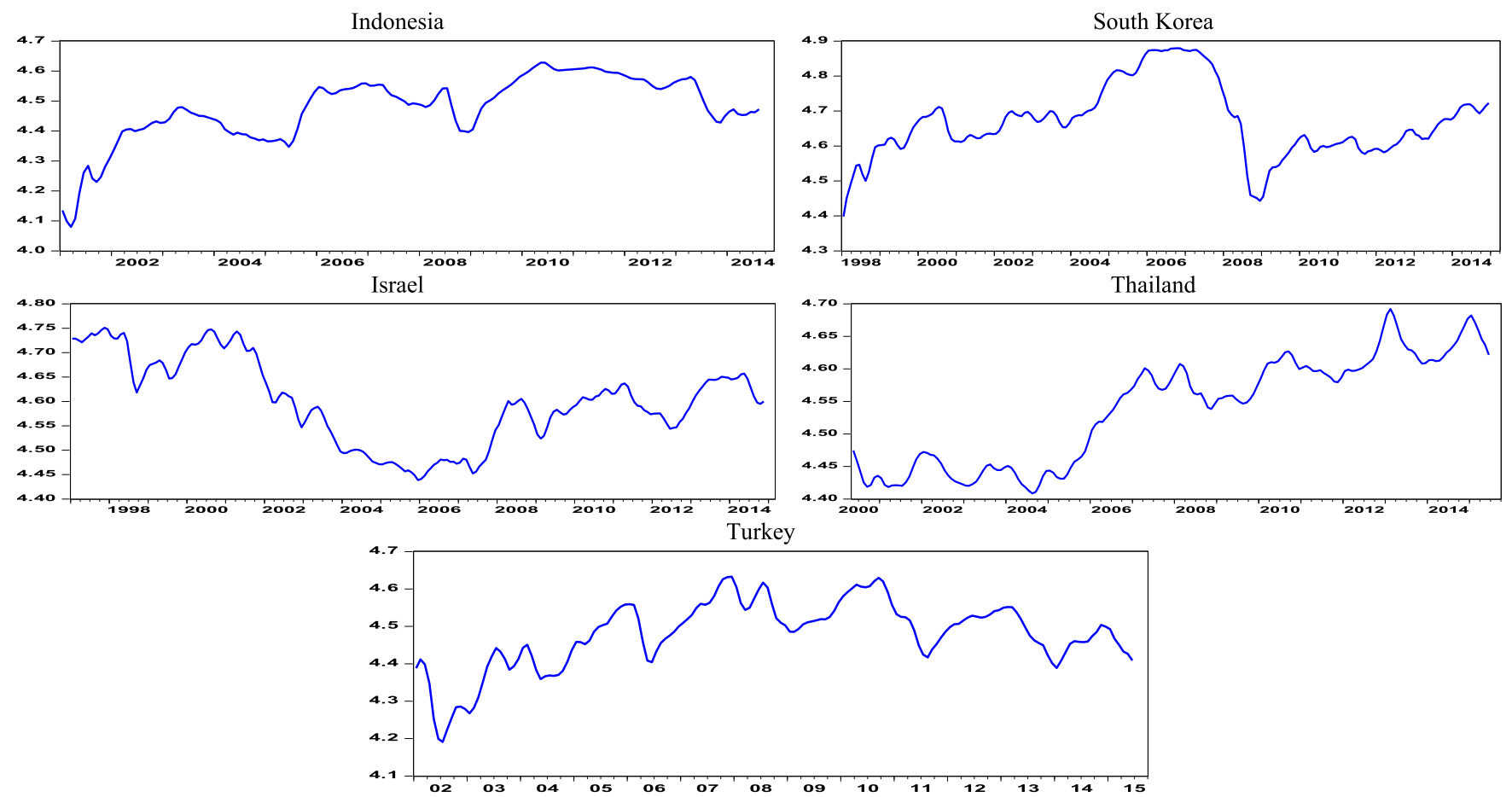

Fig. 3. The evolution of the real effective exchange rates.
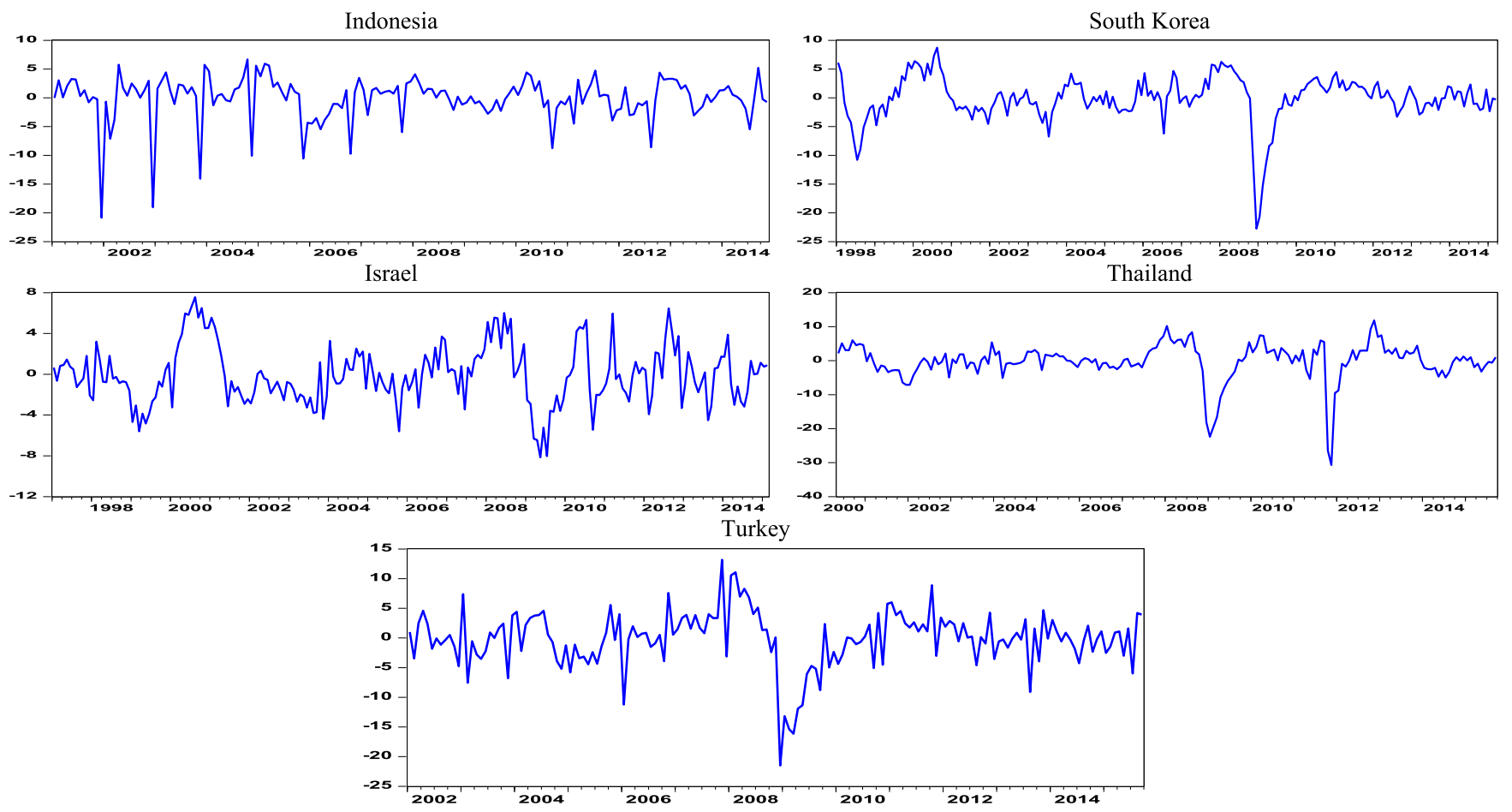

Fig. 4. The evolution of output gaps.

\section{Empirical results}

\subsection{Linear Taylor rule results}

The linear estimation results are reported in Table 3. We use the GMM estimator with an optimal weighting matrix, which takes into account possible serial correlation (Hansen, 1982). Following Clarida et al.
(1998) and Taylor and Davradakis (2006), a constant and the sixth, the ninth and the twelfth lags of each variable in the regression models, i.e., the interest rate, inflation gap, output gap and real effective exchange rate, are chosen as instruments. If their number and that of the orthogonality conditions exceed the number of estimated parameters, the regression is over-identified. To investigate the validity of our instruments, we carry out Sargan tests, the null hypothesis being that the 
Table 1

Linear unit root tests.

\begin{tabular}{|c|c|c|c|c|c|c|c|}
\hline & & \multicolumn{2}{|l|}{ ADF Test } & \multicolumn{2}{|l|}{ PP Test } & \multicolumn{2}{|l|}{ KPSS Test } \\
\hline & & Intercept & Intercept \& Trend & Intercept & Intercept \& Trend & Intercept & Intercept \& Trend \\
\hline \multirow[t]{4}{*}{ Indonesia } & $r_{t}$ & -2.052 & -2.051 & -1.743 & -1.491 & $2.052^{* * *}$ & $0.274 * * *$ \\
\hline & $\pi_{t+k}$ & $-3.363^{* *}$ & $-3.363^{*}$ & $-2.718^{*}$ & -2.746 & 0.273 & 0.092 \\
\hline & $r e r_{t+k}$ & $-3.951^{* * *}$ & $-4.138^{* * *}$ & $-3.215^{* *}$ & -2.567 & $1.819 * * *$ & $0.320 * * *$ \\
\hline & $y_{t+k}$ & $-11.656^{* * *}$ & $-11.622^{* * *}$ & $-11.814^{* * *}$ & $-11.815^{* *}$ & 0.028 & 0.027 \\
\hline \multirow[t]{4}{*}{ Israel } & $r_{t}$ & $-1.865-$ & $-3.324 *$ & -1.950 & -2.861 & $3.802^{* * *}$ & $0.547^{* * *}$ \\
\hline & $\pi_{t+k}$ & $-3.589 * * *$ & $-3.607 * *$ & $-3.036^{* *}$ & -3.093 & $0.354^{*}$ & $0.121^{*}$ \\
\hline & $r e r_{t+k}$ & -2.008 & -1.591 & -1.774 & -1.515 & $1.422 * * *$ & $0.837 * * *$ \\
\hline & $y_{t+k}$ & $-4.919 * * *$ & $-4.907 * * *$ & $-6.418^{* * *}$ & $-6.418^{* * *}$ & 0.042 & 0.042 \\
\hline \multirow[t]{4}{*}{ South Korea } & $r_{t}$ & $-9.486 * * *$ & $-6.810^{* * *}$ & $-11.265^{* * *}$ & $-10.778^{* * *}$ & $1.493 * * *$ & $0.255^{* * *}$ \\
\hline & $\pi_{t+k}$ & $-3.183^{* *}$ & $-3.165^{\star}$ & $-2.702^{*}$ & -2.692 & $0.379 *$ & $0.380^{* * *}$ \\
\hline & $r e r_{t+k}$ & -2.258 & -2.281 & $-2.684^{*}$ & -2.653 & $0.469^{*}$ & $0.478^{* * *}$ \\
\hline & $y_{t+k}$ & $-4.433^{* * *}$ & $-4.428^{* * *}$ & $-4.830^{* * *}$ & $-4.834 * * *$ & 0.040 & 0.039 \\
\hline \multirow[t]{4}{*}{ Thailand } & $r_{t}$ & -2.088 & -2.072 & -1.721 & -1.656 & 0.311 & $0.281^{* * *}$ \\
\hline & $\pi_{t+k}$ & $-3.009^{* *}$ & -2.985 & -2.521 & -2.537 & 0.258 & $0.249^{* * *}$ \\
\hline & $r e r_{t+k}$ & -1.247 & -2.564 & -0.946 & -2.933 & $3.304 * * *$ & $0.200 * *$ \\
\hline & $y_{t+k}$ & $-5.313^{* * *}$ & $-5.297^{* *}$ & $-5.392^{* * *}$ & $-5.390 * * *$ & 0.031 & 0.030 \\
\hline \multirow[t]{4}{*}{ Turkey } & $r_{t}$ & $-4.834^{* * *}$ & $-3.595^{* *}$ & $-5.245^{* * *}$ & $-3.413^{*}$ & $2.428^{* * *}$ & $0.511^{* * *}$ \\
\hline & $\pi_{t+k}$ & $-4.386^{* * *}$ & $-4.571^{* * *}$ & $-6.956^{* * *}$ & $-6.956 * * *$ & 0.082 & 0.082 \\
\hline & $r e r_{t+k}$ & $-2.857^{*}$ & -2.301 & -2.200 & -2.094 & $1.086^{* * *}$ & $0.560^{* * *}$ \\
\hline & $y_{t+k}$ & $-4.110^{* * *}$ & $-4.096^{* * *}$ & $-8.848^{* * *}$ & $-8.847 * * *$ & $0.061^{*}$ & 0.060 \\
\hline
\end{tabular}

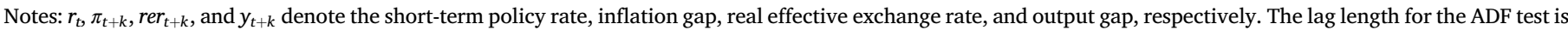

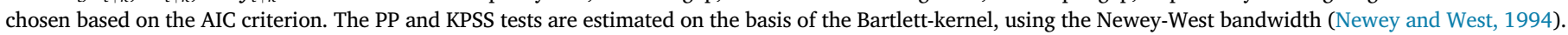

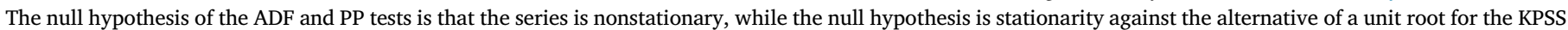
test. $* * *, * *$ and $*$ indicate statistical significance at the $1 \%, 5 \%$ and $10 \%$ levels, respectively.

over-identifying restrictions are valid (Sargan, 1958). This cannot be rejected at the $5 \%$ level in any case, which confirms the exogeneity of the instruments.

The coefficients of the Taylor rule, on the other hand, differ across the countries under investigation in terms of size, sign and statistical significance. More specifically, the coefficient on the lagged interest rate $\left(\alpha_{1}\right)$ is highly significant and close to one in all cases. This implies that the monetary authorities of the countries under consideration adjust their interest rate with the smoothing parameter. There is also evidence that they respond to deviations of inflation from its target. The estimate of $\alpha_{2}$ is significant and positive in all countries, except South Korea. Further, they react to the output gap in Indonesia and Israel as the coefficient $\alpha_{3}$ is positive and significant. In the case of Thailand, $\alpha_{3}$ is significant as well but negative ( $\left.\alpha_{3}=-0.015\right)$, whilst it is small and insignificant in South Korea and Turkey. Finally, there is no evidence of any response to exchange rate movements in all countries, except Turkey $\left(\alpha_{4}=0.483\right)$.

Overall, our findings support the existence of a Taylor rule in Indonesia, Israel, Thailand and Turkey, but not in South Korea, where the coefficients on both the output and inflation gaps are found to be statistically insignificant. These results also suggest that policy makers in the countries considered respond more to deviations from target in the case of inflation as opposed to output. Next we examine whether there is any evidence of nonlinearities.

\subsection{Threshold Taylor rule results}

As emphasised in the recent literature, there are various reasons why the reaction function of monetary authorities might not be linear: for instance, if the weights on positive and negative output and inflation gaps respectively are not the same, the behaviour of the central bank might be better described by a nonlinear Taylor rule (see, e.g., Robert-Nobay and Peel, 2003; Dolado et al., 2005; Taylor and Davradakis, 2006; Surico, 2007; Castro, 2011; Martin and Milas, 2004, 2013; Caglayan et al., 2016, Klingelhöfer and Sun, 2018).
As already mentioned, we use GMM to estimate the threshold model given by Eq. (5) because this method takes into account the possible correlation between the regressors; it is ideally suited to modelling the possibly asymmetric behaviour of central banks since it treats regime switches as endogenous, and it allows to estimate the optimal threshold value of inflation for each country - this is chosen as the threshold indicator since monetary policy typically places more weight on inflation (Castro, 2011; Martin and Milas, 2013; Jawadi et al., 2014). The optimum threshold values obtained from the grid search based on the minimisation of the condition given by Eq. (7) are reported in Table 4. Turkey has the highest value $\left(\pi^{*}=8 \%\right)$, followed by Indonesia $\left(\pi^{*}=6 \%\right)$. Israel and South Korea have the same (lower) value $\left(\pi^{*}=\right.$ $3 \%)$, while Thailand has the lowest one $\left(\pi^{*}=1 \%\right)$. In order to compare linear and threshold models in terms of goodness of fit, following Taylor and Davradakis (2006) we applied quasi likelihood ratio $(Q-L R)$ test statistics as follows:

$Q-L R=J^{\text {lin }}-J^{\text {thres }}$,

where $J^{\text {lin }}$ and $J^{\text {thres }}$ are the objective function that GMM minimizes for the linear and threshold models respectively. Significance levels of the QLR statistics derived from a non-parametric bootstrap simulations based on Hansen (1996) are reported at the bottom of Table 4. The results confirm the existence of threshold effects in all countries by rejecting the null hypothesis of linear model, i.e. $H_{0}: \beta_{1}^{L}=\beta_{1}^{H}, \quad \beta_{2}^{L}=\beta_{2}^{H}, \quad \beta_{3}^{L}=\beta_{3}^{H}$, $\beta_{4}^{L}=\beta_{4}^{H} \cdot{ }^{5}$ More specifically, Regime 1 is the high inflation regime where the inflation rate exceeds its optimum threshold value $\pi_{t-1} \geq \pi^{*}$, whilst regime 2 is the low inflation regime, where $\pi_{t-1}<\pi^{*}$ (see Fig. 5 for the regime classifications). Therefore, the inflation rate appears to be the

\footnotetext{
${ }^{5}$ In the estimation of the threshold GMM we use the RATS codes of Taylor and Davradakis (2006). For more details on the steps of the Q-LR test, see Taylor and Davradakis (2006).
} 
Table 2

Nonlinear unit root tests.

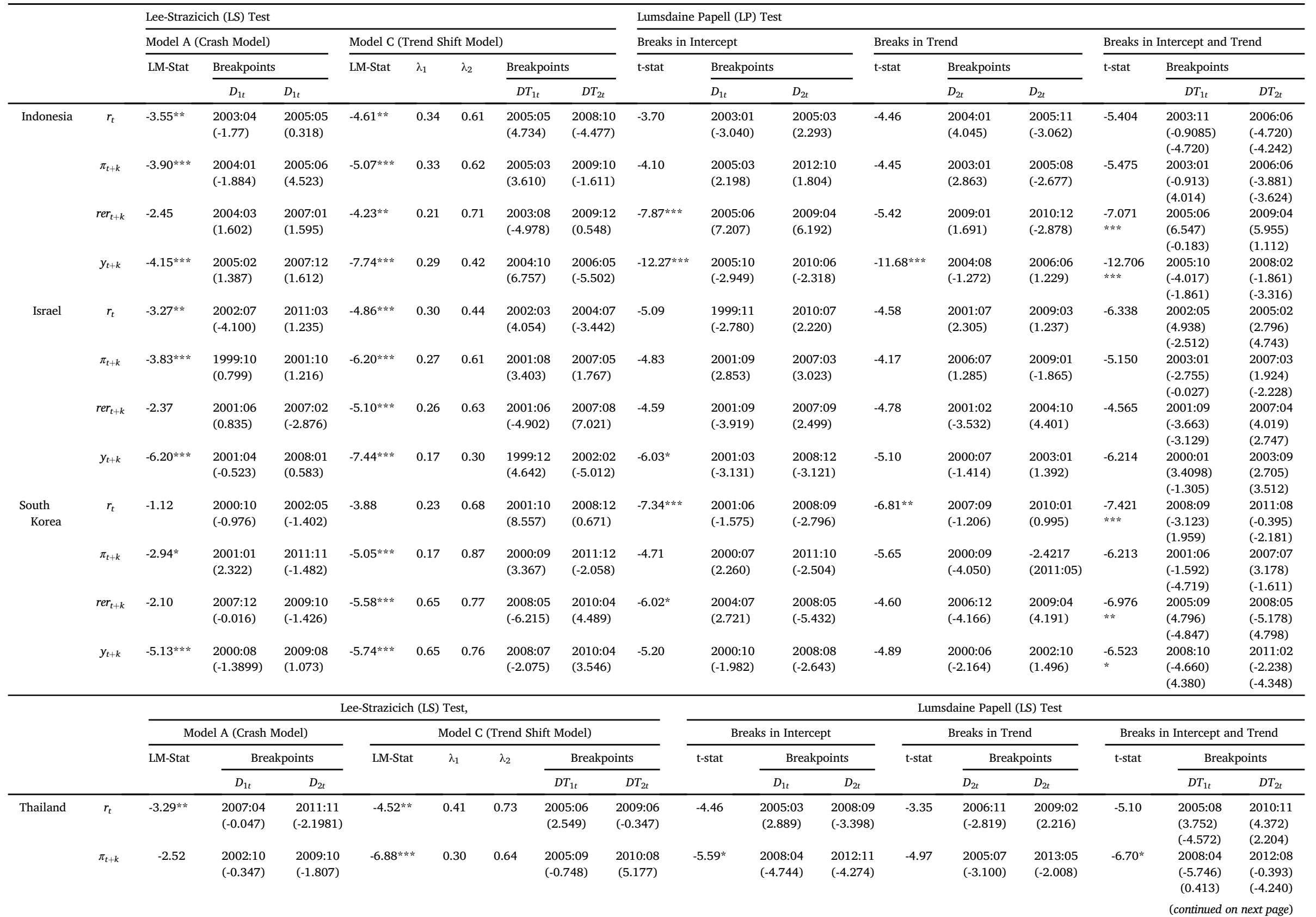




\begin{tabular}{|c|c|c|c|c|c|c|c|c|c|c|c|c|c|c|c|c|c|c|}
\hline & & \multicolumn{8}{|c|}{ Lee-Strazicich (LS) Test, } & \multicolumn{9}{|c|}{ Lumsdaine Papell (LS) Test } \\
\hline & & \multicolumn{3}{|c|}{ Model A (Crash Model) } & \multicolumn{5}{|c|}{ Model C (Trend Shift Model) } & \multicolumn{3}{|c|}{ Breaks in Intercept } & \multicolumn{3}{|c|}{ Breaks in Trend } & \multicolumn{3}{|c|}{ Breaks in Intercept and Trend } \\
\hline & & \multirow[t]{2}{*}{ LM-Stat } & \multicolumn{2}{|c|}{ Breakpoints } & \multirow[t]{2}{*}{ LM-Stat } & \multirow[t]{2}{*}{$\lambda_{1}$} & \multirow[t]{2}{*}{$\lambda_{2}$} & \multicolumn{2}{|c|}{ Breakpoints } & \multirow[t]{2}{*}{ t-stat } & \multicolumn{2}{|c|}{ Breakpoints } & \multirow[t]{2}{*}{ t-stat } & \multicolumn{2}{|c|}{ Breakpoints } & \multirow[t]{2}{*}{ t-stat } & \multicolumn{2}{|c|}{ Breakpoints } \\
\hline & & & $D_{1 t}$ & $D_{2 t}$ & & & & $D T_{1 t}$ & $D T_{2 t}$ & & $D_{1 t}$ & $D_{2 t}$ & & $D_{2 t}$ & $D_{2 t}$ & & $D T_{1 t}$ & $D T_{2 t}$ \\
\hline & $r e r_{t+k}$ & $-3.22^{* *}$ & $\begin{array}{c}2004: 10 \\
(0.375)\end{array}$ & $\begin{array}{l}\text { 2013:03 } \\
(-0.379)\end{array}$ & $-5.94 * * *$ & 0.19 & 0.36 & $\begin{array}{c}2004: 02 \\
(2.117)\end{array}$ & $\begin{array}{c}2006: 06 \\
(2.958)\end{array}$ & -4.73 & $\begin{array}{c}2005: 11 \\
(4.049)\end{array}$ & $\begin{array}{c}2009: 11 \\
(1.760)\end{array}$ & -4.91 & $\begin{array}{c}2005: 01 \\
(3.908)\end{array}$ & $\begin{array}{l}2007: 02 \\
(-4.263)\end{array}$ & -5.85 & $\begin{array}{l}2004: 11 \\
(-1.826) \\
(5.039)\end{array}$ & $\begin{array}{c}2008: 02 \\
(-4.531) \\
(-4.996)\end{array}$ \\
\hline & $y_{t+k}$ & $-6.13^{* * *}$ & $\begin{array}{c}2003: 08 \\
(0.572)\end{array}$ & $\begin{array}{l}2011: 02 \\
(1.824)\end{array}$ & $-7.54^{* * *}$ & 0.72 & 0.88 & $\begin{array}{c}2011: 09 \\
(7.061)\end{array}$ & $\begin{array}{l}2013: 10 \\
(-6.013)\end{array}$ & -5.78 & $\begin{array}{l}2008: 08 \\
(-1.935)\end{array}$ & $\begin{array}{c}2012: 01 \\
(1.221)\end{array}$ & -5.32 & $\begin{array}{l}2007: 02 \\
(-0.733)\end{array}$ & $\begin{array}{c}2009: 03 \\
(0.763)\end{array}$ & -6.59 & $\begin{array}{c}2008: 10 \\
(-3.742) \\
(3.370)\end{array}$ & $\begin{array}{l}2010: 11 \\
(-2.268) \\
(-3.285)\end{array}$ \\
\hline \multirow[t]{4}{*}{ Turkey } & $r_{t}$ & -1.07 & $\begin{array}{l}2006: 07 \\
(-1.383)\end{array}$ & $\begin{array}{l}\text { 2011:07 } \\
(4.954)\end{array}$ & -3.65 & 0.24 & 0.69 & $\begin{array}{c}2005: 01 \\
(6.892)\end{array}$ & $\begin{array}{l}2010: 10 \\
(-0.121)\end{array}$ & -4.34 & $\begin{array}{c}2011: 07 \\
(1.653)\end{array}$ & $\begin{array}{c}2013: 11 \\
(1.784)\end{array}$ & -3.83 & $\begin{array}{c}2004: 01 \\
(2.072)\end{array}$ & $\begin{array}{c}2011: 01 \\
(2.263)\end{array}$ & -4.81 & $\begin{array}{l}2004: 08 \\
(-1.111) \\
(3.494)\end{array}$ & $\begin{array}{l}2008: 12 \\
(-4.328) \\
(-0.332)\end{array}$ \\
\hline & $\pi_{t+k}$ & -0.86 & $\begin{array}{c}2009: 12 \\
(3.576)\end{array}$ & $\begin{array}{l}\text { 2013:03 } \\
(1.665)\end{array}$ & $-6.27^{* * *}$ & 0.18 & 0.56 & $\begin{array}{c}2004: 03 \\
(8.110)\end{array}$ & $\begin{array}{l}2008: 12 \\
(-3.085)\end{array}$ & $-7.97^{* * *}$ & $\begin{array}{c}2005: 12 \\
(4.388)\end{array}$ & $\begin{array}{l}2008: 12 \\
(-5.034)\end{array}$ & $-6.41^{*}$ & $\begin{array}{l}2008: 04 \\
(-4.207)\end{array}$ & $\begin{array}{c}2010: 04 \\
(3.643)\end{array}$ & $-7.80^{* * *}$ & $\begin{array}{c}2005: 12 \\
(3.982) \\
(1.823)\end{array}$ & $\begin{array}{l}2008: 12 \\
(-4.977) \\
(-0.399)\end{array}$ \\
\hline & $r e r_{t+k}$ & $-4.11^{* * *}$ & $\begin{array}{c}2008: 02 \\
(2.105)\end{array}$ & $\begin{array}{l}2010: 10 \\
(-0.687)\end{array}$ & $-6.61^{* * *}$ & 0.47 & 0.64 & $\begin{array}{l}2007: 11 \\
(-1.161)\end{array}$ & $\begin{array}{c}2009: 12 \\
(4.203)\end{array}$ & -5.40 & $\begin{array}{c}2004: 08 \\
(3.939)\end{array}$ & $\begin{array}{c}2006: 08 \\
(3.704)\end{array}$ & -5.72 & $\begin{array}{l}2007: 10 \\
(-3.752)\end{array}$ & $\begin{array}{l}2010: 08 \\
(-2.247)\end{array}$ & -6.47 & $\begin{array}{l}2008: 07 \\
(-3.399) \\
(-1.841)\end{array}$ & $\begin{array}{l}2011: 02 \\
(-2.113) \\
(-3.240)\end{array}$ \\
\hline & $y_{t+k}$ & $\begin{array}{l}-4.23 \\
* * * * *\end{array}$ & $\begin{array}{c}2008: 01 \\
(2.642)\end{array}$ & $\begin{array}{l}2009: 12 \\
(-2.093)\end{array}$ & -5.87 & 0.31 & 0.52 & $\begin{array}{c}2005: 12 \\
(4.977)\end{array}$ & $\begin{array}{l}2008: 08 \\
(-5.279)\end{array}$ & -5.44 & $\begin{array}{l}2008: 07 \\
(-3.327)\end{array}$ & $\begin{array}{c}2010: 05 \\
(1.941)\end{array}$ & -4.45 & $\begin{array}{l}2007: 06 \\
(-1.633)\end{array}$ & $\begin{array}{c}2009: 04 \\
(1.796)\end{array}$ & $-7.84^{* * *}$ & $\begin{array}{c}2008: 11 \\
(-6.401) \\
(5.082)\end{array}$ & $\begin{array}{l}2010: 09 \\
(-0.151) \\
(-5.452)\end{array}$ \\
\hline
\end{tabular}

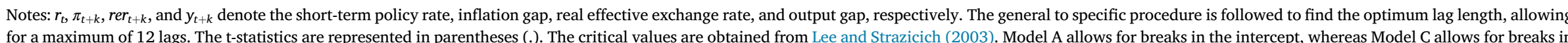

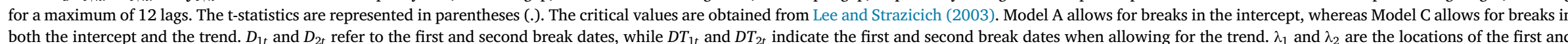

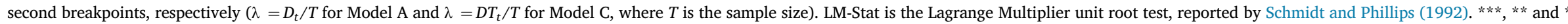
indicate statistical significance at the $1 \%, 5 \%$, and $10 \%$ levels, respectively. 
Table 3

Linear Taylor rule based on GMM.

\begin{tabular}{clllll}
\hline & Indonesia & Israel & $\begin{array}{l}\text { South } \\
\text { Korea }\end{array}$ & Thailand & Turkey \\
\hline$\alpha_{0}$ & -0.914 & 0.131 & 0.148 & 0.344 & $-2.289^{* * *}$ \\
& $(0.792)$ & $(0.729)$ & $(0.240)$ & $(0.354)$ & $(0.922)$ \\
$\alpha_{1}$ & $0.952^{* * *}$ & $0.981^{* * *}$ & $1.003^{* * *}$ & $0.985^{* * *}$ & $0.977^{* * *}$ \\
& $(0.006)$ & $(0.004)$ & $(0.004)$ & $(0.006)$ & $(0.002)$ \\
$\alpha_{2}$ & $0.058^{* * *}$ & $0.036^{* * *}$ & -0.004 & $0.026^{* * *}$ & $0.082^{* * *}$ \\
& $(0.004)$ & $(0.006)$ & $(0.004)$ & $(0.004)$ & $(0.006)$ \\
$\alpha_{3}$ & $0.026^{* * *}$ & $0.012^{*}$ & -0.002 & $-0.015^{* * *}$ & 0.001 \\
& $(0.006)$ & $(0.007)$ & $(0.002)$ & $(0.002)$ & $(0.003)$ \\
$\alpha_{4}$ & 0.258 & -0.022 & -0.032 & -0.070 & $0.483^{* * *}$ \\
& $(0.171)$ & $(0.160)$ & $(0.052)$ & $(0.078)$ & $(0.203)$ \\
Sargan & 50.35 & 53.18 & 52.38 & 56.56 & 41.58 \\
Test & {$[0.236]$} & {$[0.161]$} & {$[0.181]$} & {$[0.096]$} & {$[0.575]$} \\
\hline
\end{tabular}

Notes: The estimated model is specified as.

$r_{t}=\alpha_{0}+\alpha_{1} r_{t-1}+\alpha_{2} \sum_{k=1}^{3}\left(E_{t-1} \pi_{t+k}-\pi^{t}\right)+\alpha_{3} \sum_{k=1}^{3}\left(E_{t-1} y_{t+k}\right)+\alpha_{4} \sum_{k=1}^{3}\left(E_{t-1}\right.$ rer $\left._{t+k}\right)+\varepsilon_{t}$,

where $r_{t}, \pi_{t+k}, r e r_{t+k}$, and $y_{t+k}$ denote the short-term policy rate, inflation gap, real effective exchange rate, and output gap, respectively, while $\pi^{t}$ is the inflation target. Standard errors are represented in parentheses (.). The probabilities of the Sargan test statistics are given in square brackets [.]. The set of instruments includes a constant and the sixth, the ninth and the twelfth lags of each variable in the estimated model. The horizons of the real effective exchange rate, and output and inflation gaps are, respectively, the 3-month lead average of the real exchange rate, and output and inflation gaps (Svensson, 1997; Martin and Milas, 2013; Ahmad, 2016). ${ }^{* * *}, * *$ and * indicate statistical significance at the $1 \%, 5 \%$, and $10 \%$ levels, respectively

appropriate switching indicator for all countries in our sample. Table A2 in Appendix A gives details of the identified regimes for each country.

The estimation results for the nonlinear Taylor rule are reported in Table 4. The interest rate smoothing coefficient is close to unity in both regimes in all countries, except in Thailand in the low inflation regime $\left(\beta_{1}^{L}=0.575\right)$. This confirms the smoothness in interest rate adjustment by the monetary authorities for the countries in our sample. There is clear evidence that monetary authorities react to the inflation gap in a nonlinear manner. The coefficient on the inflation gap is positive and significant in Israel, South Korea and Thailand in both regimes, but its size is not the same in the two regimes (see $\beta_{2}^{L}$ and $\beta_{2}^{H}$ in Table 4). In Indonesia, it is only positive and significant when the inflation rate exceeds its target level, whilst in Turkey it is significant and positive in the low inflation regime only. The evidence for Turkey suggests that the interest rate channel of monetary transmission may work properly only in a low-inflation environment as previously documented by Çatık and Karaçuka (2012).

The coefficient on the output gap is positive and significant in Indonesia and Israel (but negative and significant in Thailand) in the high inflation regime, and in South Korea and Turkey in the low inflation one. Our findings are consistent with those of other empirical studies finding that a contractionary monetary policy has a negative impact on output (Mallick and Sousa, 2012; Jawadi et al., 2014). Finally, the estimated coefficient on the real effective exchange rate implies that the central bank reacts to its fluctuations only in the low inflation regime $\left(\beta_{4}^{L}\right.$ is positive and significant in Indonesia, South Korea and Thailand and negative and significant in Israel). It seems therefore that the real effective exchange rate has an important role in determining the behaviour of central banks in emerging markets in the low inflation regime. This finding is consistent with the literature suggesting that emerging markets have an implicit comfort zone for smoothing exchange rate fluctuations, even if they do not specify an exchange rate target (see also Ghosh et al., 2016; de la Torre et al., 2013; Mohanty, 2013).
Table 4

Nonlinear (threshold) Taylor rule based on GMM.

\begin{tabular}{|c|c|c|c|c|c|}
\hline & Indonesia & Israel & $\begin{array}{l}\text { South } \\
\text { Korea }\end{array}$ & Thailand & Turkey \\
\hline$\pi^{*}$ & 0.06 & 0.03 & 0.03 & 0.01 & 0.08 \\
\hline \multicolumn{6}{|c|}{ Panel A: Regime 1 (high inflation) } \\
\hline \multirow{2}{*}{$\beta_{0}^{H}$} & 0.872 & -8.574 & -1.761 & 1.027 & 2.031 \\
\hline & (1.637) & $(7.028)$ & $(1.283)$ & $(0.786)$ & $(1.377)$ \\
\hline \multirow[t]{2}{*}{$\beta_{1}^{H}$} & $0.979 * * *$ & $0.998^{* * *}$ & $0.984 * * *$ & $0.982^{* * *}$ & $0.992^{* * *}$ \\
\hline & $(0.005)$ & $(0.012)$ & $(0.017)$ & $(0.008)$ & $(0.005)$ \\
\hline \multirow{2}{*}{$\beta_{2}^{H}$} & $0.050 * * *$ & $0.056^{* * *}$ & $0.070^{* * *}$ & $0.0604 * * *$ & -0.006 \\
\hline & $(0.006)$ & $(0.017)$ & $(0.028)$ & $(0.011)$ & $(0.021)$ \\
\hline \multirow[t]{2}{*}{$\beta_{3}^{H}$} & $0.053^{* * *}$ & $0.041 * * *$ & 0.006 & $-0.021 * * *$ & -0.002 \\
\hline & $(0.011)$ & $(0.014)$ & $(0.005)$ & $(0.002)$ & $(0.003)$ \\
\hline \multirow[t]{2}{*}{$\beta_{4}^{H}$} & -0.186 & 1.837 & 0.377 & -0.232 & -0.431 \\
\hline & $(0.367)$ & (1.537) & $(0.278)$ & $(0.173)$ & $(0.295)$ \\
\hline \multicolumn{6}{|c|}{ Panel B: Regime 2 (low inflation) } \\
\hline \multirow[t]{2}{*}{$\beta_{0}^{L}$} & $-8.759 * * *$ & $3.596 * * *$ & $-0.886^{* * *}$ & -5.554 & 4.414 \\
\hline & $(4.084)$ & $(2.068)$ & $(0.402)$ & (3.539) & $(3.041)$ \\
\hline \multirow[t]{2}{*}{$\beta_{1}^{L}$} & $0.891^{* * *}$ & $0.981 * * *$ & $0.927^{* * *}$ & $0.575^{* * *}$ & $0.994^{* * *}$ \\
\hline & $(0.053)$ & $(0.009)$ & $(0.010)$ & $(0.204)$ & $(0.005)$ \\
\hline \multirow[t]{2}{*}{$\beta_{2}^{L}$} & -0.021 & $0.120 * * *$ & $0.041^{* * *}$ & $0.138 * * *$ & $0.057 * * *$ \\
\hline & $(0.023)$ & $(0.027)$ & $(0.008)$ & $(0.073)$ & $(0.011)$ \\
\hline \multirow[t]{2}{*}{$\beta_{3}^{L}$} & -0.014 & 0.009 & $0.016^{* * *}$ & 0.015 & $0.046^{* * *}$ \\
\hline & $(0.016)$ & $(0.011)$ & $(0.004)$ & $(0.014)$ & $(0.008)$ \\
\hline \multirow{2}{*}{$\beta_{4}^{L}$} & $2.063^{* * *}$ & $-0.756^{* * *}$ & $0.248^{* * *}$ & $1.467 * * *$ & -1.012 \\
\hline & $(0.851)$ & $(0.451)$ & $(0.248)$ & $(0.842)$ & $(0.677)$ \\
\hline Sargan & 37.74 & 33.20 & 42.88 & 33.37 & 31.68 \\
\hline Test & [0.527] & {$[0.731]$} & {$[0.181]$} & [0.723] & [0.791] \\
\hline Q-LR & {$[0.03080]$} & {$[0.03400]$} & {$[0.02140]$} & {$[0.01500]$} & {$[0.02720]$} \\
\hline
\end{tabular}

Notes: The estimated model is specified as.

$$
\begin{aligned}
r_{t}= & I\left[\pi_{t-1}\right. \\
\geq & \left.\pi^{*}\right]\left[\beta_{0}^{H}+\beta_{1}^{H} r_{t-1}+\beta_{2}^{H} \sum_{k=1}^{3}\left(E_{t-1} \pi_{t+k}-\pi^{t}\right)+\beta_{3}^{H} \sum_{k=1}^{3}\left(E_{t-1} y_{t+k}\right)+\beta_{4}^{H}\right. \\
& \left.\times \sum_{k=1}^{3}\left(E_{t-1} \text { rer }_{t+k}\right)\right]+ \text { nflation rate (calculated as a } I\left[\pi_{t-1}\right. \\
< & \left.\pi^{*}\right]\left[\beta_{0}^{L}+\beta_{1}^{L} r_{t-1}+\beta_{2}^{L} \sum_{k=1}^{3}\left(E_{t-1} \pi_{t+k} \text { s g inflation rate },-\pi^{t}\right)+\beta_{3}^{L}\right. \\
& \left.\times \sum_{k=1}^{3}\left(E_{t-1} y_{t+k}\right)+\beta_{4}^{L} \sum_{k=1}^{3}\left(E_{t-1} \text { rer }_{t+k}\right)\right]+\varepsilon_{t},
\end{aligned}
$$

where $r_{t}, \pi_{\mathrm{t}+\mathrm{k}}, r e r_{\mathrm{t}+\mathrm{k}}$, and $y_{\mathrm{t}+\mathrm{k}}$ denote the short-term policy rate, inflation gap, real effective exchange rate, and output gap, respectively, while $\pi^{t}$ is the inflation target. Standard errors are represented in parentheses (.). The probabilities of the Sargan and Q-LR linearity tests are given in square brackets [.]. $\pi^{*}$ refers to the optimal threshold value for inflation. Regime 1 (high inflation regime) is where inflation rate exceeds its optimum threshold value $\pi_{\mathrm{t}-1} \geq \pi^{*}$, while regime 2 (low inflation regime) is where inflation rate is below its optimum threshold value $\pi_{\mathrm{t}-1} \leq \pi^{*}$. The set of instruments includes a constant and the sixth, the ninth and the twelfth lags of each variable in the estimated model. The horizons of the real effective exchange rate, and output and inflation gaps are, respectively, the 3month lead average of the real exchange rate, and inflation and output gaps (Svensson, 1997; Martin and Milas, 2013; Ahmad, 2016). ***, ** and * indicate statistical significance at the $1 \%, 5 \%$, and $10 \%$ levels, respectively.

To sum up, the results discussed above suggest that a nonlinear Taylor rule captures monetary policy in the countries under consideration better than a linear one; specifically, the reaction of monetary authorities to deviations from target of either the inflation or the output gap varies in terms of magnitude and/or statistical significance across the two inflation regimes in all countries. These findings are broadly in line with those of Miles and Schreyer (2012), who found that the central bank in Thailand responds aggressively to the deviation of inflation from target using quantile regression analysis with four different quantiles. The 


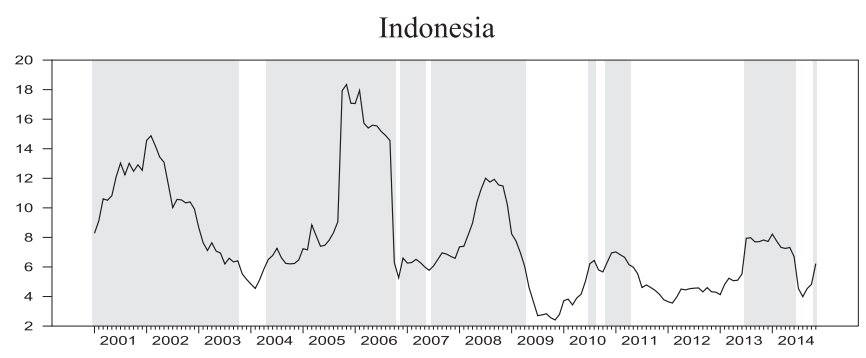

Israel

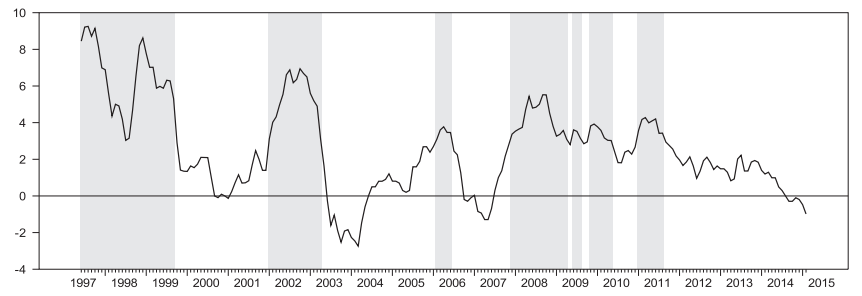

South Korea

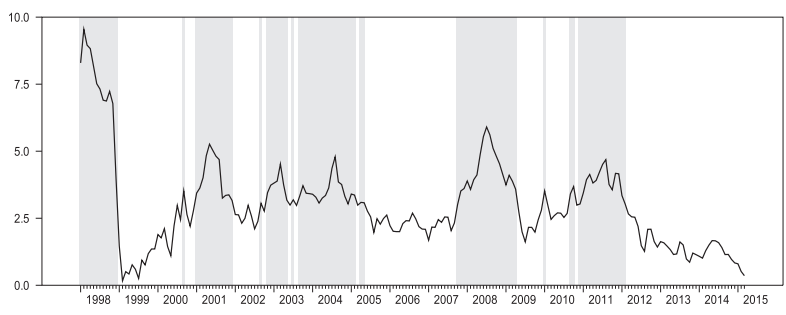

Thailand

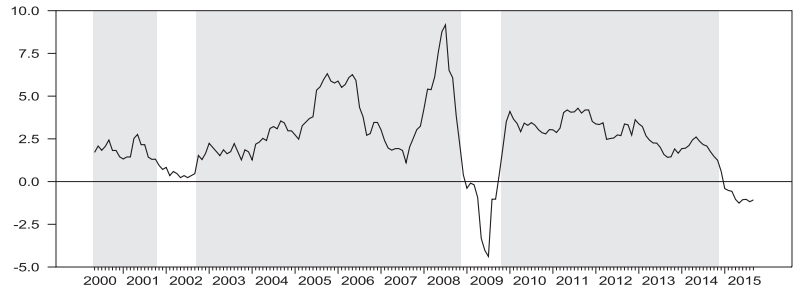

Turkey

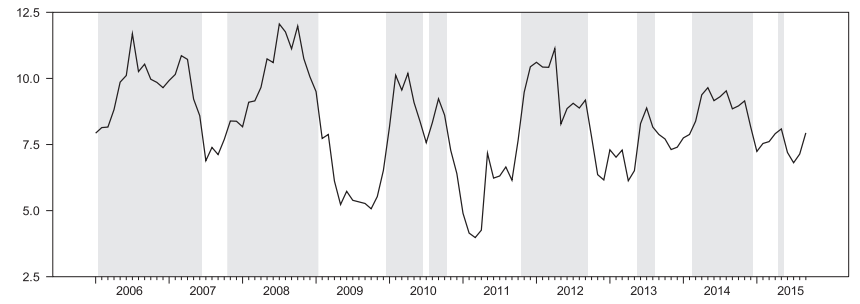

Fig. 5. Regime classifications based on inflation. Notes: the upper regime, the shaded areas, represents the high inflation regime where inflation rate exceeds its optimum threshold value $\pi_{t-1} \geq \pi^{*}$. These optimum threshold values are respectively, $\pi_{t-1} \geq 6 \%, \pi_{t-1} \geq 3 \%, \pi_{t-1} \geq 3 \%, \pi_{t-1} \geq 1 \%$, and $\pi_{t-1} \geq 8 \%$ for Indonesia, South Korea, Israel, Thailand, and Turkey which are obtained from the grid search based on the minimisation condition in Eq. (7).

nonlinear estimation also highlights the role of the exchange rate, that was not apparent in the context of the linear model: monetary authorities are now shown to respond to its movements (in the low inflation regime) in all countries in our sample except Turkey. In other words, monetary policy in these emerging countries can be described by an augmented nonlinear Taylor rule including the exchange rate. One possible explanation for the greater weight on the exchange rate in the low regime is that there is a tendency of policy makers to pursue other objectives when the inflation rate undershoots the target and rely also on the exchange rate channel for stabilising the economy (Akdoğan, 2015).

\section{Conclusions}

This paper has examined the interest rate setting behaviour of monetary authorities in five emerging countries (Indonesia, Israel, South Korea, Thailand, and Turkey) that have adopted inflation targeting. In addition to the basic linear Taylor rule, an augmented one including the exchange rate has also been considered, given the fact that monetary authorities in these countries frequently intervene in the foreign exchange markets when there are large deviations from target or to smooth out volatility (Daude et al., 2016). The pass-through from exchange rates to import and consumer prices in the emerging markets is well documented (see e.g., Ca'Zorzi et al., 2007). In the case of a depreciation side, it may force central banks targeting price stability to tighten their monetary policy, while it might lead to loss of international competition in the case of an appreciation (Gagnon and Ihrig, 2004; Baily, 2003; Bailliu and Fujii, 2004; Ghosh et al., 2016). Further, a nonlinear specification has been estimated using GMM to allow for possible asymmetries, following recent empirical studies (see Favero et al., 2000, Taylor and Davradakis, 2006; Surico, 2007; Cukierman and Muscatelli, 2008; Castro, 2011; Martin and Milas, 2004, 2013; Ahmad, 2016, among others).

The empirical findings can be summarised as follows. First, a nonlinear Taylor rule best describes the behaviour of interest rate setting in the analysed emerging markets. In particular, monetary authorities in all countries in our sample respond to deviations of inflation from target in the high inflation regime (except for Turkey) as well as in the low inflation one (except Indonesia); however, their response to deviations of output from its long-run level is only found to be significant in the high inflation regime in Indonesia and Israel and in the low inflation one in South Korea and Turkey. Second, monetary authorities in these economies respond not only to deviations of inflation and output from target but also to movements in the real exchange rate (but only when inflation is below target), except for Turkey. Cross-country differences in monetary policy responses can be rationalised in terms of economic performance, the degree of financial liberalisation, vulnerability to external shocks, and financial contagion across countries. Future research could include in the model a measure of the financial condition of countries or a stress index as the threshold variable. 


\section{Appendix A}

Table A1

Description of the data.

\begin{tabular}{|c|c|c|c|c|c|c|}
\hline & $\begin{array}{l}\text { Interest } \\
\text { rate }\end{array}$ & Inflation rate & Inflation expectations & $\begin{array}{l}\text { Exchange } \\
\text { rate }\end{array}$ & Production & \\
\hline \multirow[t]{3}{*}{$\begin{array}{l}\text { Indonesia } \\
\qquad(2001: 01-2014: 11)\end{array}$} & Definition & $\begin{array}{l}\text { Discount rate } \\
\text { (end of period) }\end{array}$ & CPI & $\begin{array}{l}\text { Inflation } \\
\text { target }\end{array}$ & $\begin{array}{l}\text { Real effective exchange rate } \\
(2010=100)\end{array}$ & $\begin{array}{l}\text { Production in total } \\
\text { manufacturing index } \\
(2010=100)\end{array}$ \\
\hline & Conversion & Level & $\begin{array}{l}\text { The } 3 \text {-month leading average of the } \\
\text { inflation rate (calculated as } \\
\text { percentage changes from the CPI) }\end{array}$ & Level & $\begin{array}{l}\text { The 3-month leading } \\
\text { average of the log real } \\
\text { effective exchange rate }\end{array}$ & $\begin{array}{l}\text { 3-month lead average of } \\
\text { the output gap. }\end{array}$ \\
\hline & $\begin{array}{l}\text { Data } \\
\text { Source }\end{array}$ & IMF & FRED & $\begin{array}{l}\text { Bank } \\
\text { Indonesia }\end{array}$ & FRED & FRED \\
\hline \multirow[t]{3}{*}{ Israel (1997:06-2015:02) } & Definition & $\begin{array}{l}\text { Discount rate } \\
\text { (end of period) }\end{array}$ & CPI & $\begin{array}{l}\text { Inflation } \\
\text { target }\end{array}$ & $\begin{array}{l}\text { Real effective exchange rate } \\
(2010=100)\end{array}$ & $\begin{array}{l}\text { Industrial production } \\
\text { index }\end{array}$ \\
\hline & Conversion & Level & $\begin{array}{l}\text { The 3-month leading average of the } \\
\text { inflation rate (calculated as } \\
\text { percentage changes from the CPI) }\end{array}$ & Level & $\begin{array}{l}\text { The 3-month leading } \\
\text { average of the log real } \\
\text { effective exchange rate }\end{array}$ & $\begin{array}{l}\text { 3-month lead average of } \\
\text { the output gap. }\end{array}$ \\
\hline & $\begin{array}{l}\text { Data } \\
\text { Source }\end{array}$ & IMF & FRED & $\begin{array}{l}\text { Bank of } \\
\text { Israel }\end{array}$ & FRED & IMF \\
\hline \multirow[t]{3}{*}{$\begin{array}{l}\text { South } \\
\text { Korea(1998:01-2015:03) }\end{array}$} & Definition & $\begin{array}{l}\text { Discount rate } \\
\text { (end of period) }\end{array}$ & CPI & $\begin{array}{l}\text { Inflation } \\
\text { target }\end{array}$ & $\begin{array}{l}\text { Real effective exchange rate } \\
(2010=100)\end{array}$ & $\begin{array}{l}\text { Industrial production } \\
\text { index }\end{array}$ \\
\hline & Conversion & Level & $\begin{array}{l}\text { The 3-month leading average of the } \\
\text { inflation rate (calculated as } \\
\text { percentage changes from the CPI) }\end{array}$ & Level & $\begin{array}{l}\text { The 3-month leading } \\
\text { average of the log real } \\
\text { effective exchange rate }\end{array}$ & $\begin{array}{l}\text { 3-month lead average of } \\
\text { the output gap. }\end{array}$ \\
\hline & $\begin{array}{l}\text { Data } \\
\text { Source }\end{array}$ & IMF & FRED & $\begin{array}{l}\text { Bank of } \\
\text { Korea }\end{array}$ & FRED & IMF \\
\hline \multirow[t]{3}{*}{ Thailand(2000:05-2015:09) } & Definition & $\begin{array}{l}\text { Discount rate } \\
\text { (end of period) }\end{array}$ & CPI & $\begin{array}{l}\text { Inflation } \\
\text { target }\end{array}$ & $\begin{array}{l}\text { Real effective exchange rate } \\
(2010=100)\end{array}$ & $\begin{array}{l}\text { Industrial production } \\
\text { index }\end{array}$ \\
\hline & Conversion & Level & $\begin{array}{l}\text { The 3-month leading average of the } \\
\text { inflation rate (calculated as } \\
\text { percentage changes from the CPI) }\end{array}$ & Level & $\begin{array}{l}\text { The 3-month leading } \\
\text { average of the log real } \\
\text { effective exchange rate }\end{array}$ & $\begin{array}{l}\text { 3-month lead average of } \\
\text { the output gap. }\end{array}$ \\
\hline & $\begin{array}{l}\text { Data } \\
\text { Source }\end{array}$ & IMF & IMF & $\begin{array}{l}\text { Bank of } \\
\text { Thailand }\end{array}$ & FRED & IMF \\
\hline \multirow[t]{3}{*}{ Turkey(2006:01-2015:09) } & Definition & $\begin{array}{l}\text { Discount rate } \\
\text { (end of period) }\end{array}$ & CPI & $\begin{array}{l}\text { Inflation } \\
\text { target }\end{array}$ & $\begin{array}{l}\text { Real effective exchange rate } \\
(2010=100)\end{array}$ & $\begin{array}{l}\text { Industrial production } \\
\text { index }\end{array}$ \\
\hline & Conversion & Level & $\begin{array}{l}\text { The 3-month leading average of the } \\
\text { inflation rate (calculated as } \\
\text { percentage changes from the CPI) }\end{array}$ & Level & $\begin{array}{l}\text { The 3-month leading } \\
\text { average of the log real } \\
\text { effective exchange rate }\end{array}$ & $\begin{array}{l}\text { 3-month lead average of } \\
\text { the output gap. }\end{array}$ \\
\hline & $\begin{array}{l}\text { Data } \\
\text { Source }\end{array}$ & IMF & IMF & CBRT & FRED & IMF \\
\hline
\end{tabular}

Note: FRED is the Federal Reserve Economic Data and CBRT is the Central Bank of the Republic of Turkey.

Table A2

Regime classifications.

\begin{tabular}{lll}
\hline & Regime 1 (high inflation) & Regime 2 (low inflation) \\
\hline Indonesia (2001:01-2014:11) & $2001: 01-2003: 08$ & $2003: 09-2004: 02$ \\
& $2004: 03-2007: 03$ & $2007: 04$ \\
& $2007: 05-2009: 01$ & $2009: 02-2010: 05$ \\
& $2010: 06$ & $2010: 07-2010: 08$ \\
& $2010: 09-2011: 02$ & $2011: 03-2013: 03$ \\
& $2013: 04-2014: 04$ & $2014: 05-2014: 08$ \\
& & \\
& $1997: 01-1999: 08$ & $1999: 09-2001: 11$ \\
& $2001: 12-2003: 02$ & $2003: 03-2005: 11$ \\
& $2005: 12-2006: 04$ & $2006: 05-2007: 09$ \\
& $2007: 10-2009: 06$ & $2009: 7$ \\
& $2009: 08-2010: 02$ & $2010: 03-2010: 10$ \\
& $2010: 11-2011: 07$ & $2011: 08-2014: 11$ \\
& & \\
Israel (1997:06-2015:02) & $1998: 01-1998: 10$ & $1998: 11-2000: 10$ \\
& $2000: 11-2001: 10$ & $2001: 11-2002: 07$ \\
& $2002: 08-2005: 02$ & $2005: 03-2007: 08$ \\
& $2007: 09-2009: 02$ & $2009: 03-2009: 10$ \\
& $2009: 11$ & $2009: 12-2010: 06$ \\
& $2010: 07-2011: 12$ & $2012: 01-2014: 12$ \\
& & \\
Thailand (2000:05-2015:09) & $2000: 05-2001: 08$ & $2001: 09-2002: 07$ \\
& $2002-08-2008: 09$ & $2008: 10-2009: 08$ \\
& $2009: 09-2014: 09$ & $2014: 10-2015: 06$ \\
& $2006: 01-2007: 04$ & \\
& & $2007: 05-2007: 08$ \\
& & (continued on next page)
\end{tabular}




\begin{tabular}{ll}
\hline Regime 1 (high inflation) & Regime 2 (low inflation) \\
\hline $2007: 09-2008: 12$ & $2009: 01-2009: 10$ \\
$2009: 11-2010: 08$ & $2010: 09-2011: 08$ \\
$2011: 09-2012: 07$ & $2012: 08-2013: 04$ \\
$2013: 05-2013: 06$ & $2013: 07-2013: 11$ \\
$2013: 12-2014: 10$ & $2014: 11-2015: 06$ \\
\hline
\end{tabular}

Note: Regime 1 is the high inflation regime where the inflation rate exceeds its optimum threshold value $\pi_{t-1} \geq \pi^{*}$, whilst regime 2 is the low inflation regime, where. $\pi_{t-1}<\pi^{*}$.

\section{References}

Adolfson, M., Laséen, S., Lindé, J., Villani, M., 2008. Empirical properties of closed-and open-economy DSGE models of the euro area. Macroecon. Dyn. 12 (S1), 2-19.

Ahmad, S., 2016. A multiple threshold analysis of the Fed's balancing act during the Great Moderation. Econ. Modell. 55, 343-358.

Aizenman, J., Hutchison, M., Noy, I., 2011. Inflation targeting and real exchange rates in emerging markets. World Dev. 39 (5), 712-724.

Akdoğan, K., 2015. Asymmetric behaviour of inflation around the target in inflationtargeting countries. Scot. J. Polit. Econ. 62 (5), 486-504.

Akyürek, C., Kutan, A.M., Yilmazkuday, H., 2011. Can inflation targeting regimes be effective in developing countries? The Turkish experience. J. Asian Econ. 22 (5), 343-355.

Astley, M.S., Giese, J., Hume, M.J., Kubelec, C., 2009. Global Imbalances and the Financial Crisis. Bank of England Quarterly Bulletin. Q3.

Atanasova, C., 2003. Credit market imperfections and business cycle dynamics: a nonlinear approach. Stud. Nonlinear Dynam. Econom. 7 (4).

Bae, J., Kim, C., Kim, D.H., 2012. The evolution of the monetary policy regimes in the US Empir. Econ. 43 (2), 617-649.

Bailliu, J., Fujii, E., 2004. Exchange Rate Pass-through and the Inflation Environment in Industrialized Countries: an Empirical Investigation. Bank of Canada Working Paper 2004-21.

Baily, M.N., 2003. Persistent dollar swings and the US economy. In: Williamson, J. (Ed.), Dollar Overvaluation and the World Economy. Institute of International Economics (US).

Balke, N.S., 2000. Credit and economic activity: credit regimes and nonlinear propagation of shocks. Rev. Econ. Stat. 82 (2), 344-349.

Ball, L., 1999. Policy rules for open economies. In: Taylor, J.B. (Ed.), Monetary Policy Rules. University of Chicago Press, pp. 127-156.

Ball, L., 2000. Policy Rules and External Shocks. National Bureau of Economic Research Working Paper, 7910

Banerjee, A., Lumsdaine, R.L., Stock, J.H., 1992. Recursive and sequential tests of the unit-root and trend-break hypotheses: theory and international evidence. J. Bus. Econ. Stat. 10 (3), 271-287.

Bernanke, B.S., Mishkin, F.S., 1997. Inflation Targeting: a New Framework for Monetary Policy? (No. W5893) National Bureau of Economic Research.

Bernanke, B.S., 2004. The Great Moderation. Eastern Economic Association, Washington, DC. February 20.

Brenner, M., Sokoler, M., 2010. Inflation targeting and exchange rate regimes: evidence from the financial markets. Rev. Finance 14 (2), 295-311.

Caglayan, M., Jehan, Z., Mouratidis, K., 2016. Asymmetric monetary policy rules for an open economy: evidence from Canada and the UK. Int. J. Finance Econ. https:// doi.org/10.1002/ijfe.1547.

Calvo, G.A., Reinhart, C.M., 2002. Fear of floating Q. J. Econ. 117 (2), 379-408.

Carlson, M., 2007. A Brief History of the 1987 Stock Market Crash with a Discussion of the Federal Reserve Response. Divisions of Research \& Statistics and Monetary Affairs, Federal Reserve Board.

Çatık, A.N., Karaçuka, M., 2012. The bank lending channel in Turkey: has it changed after the low inflation regime? Appl. Econ. Lett. 19 (13), 1237-1242.

Castro, V., 2011. Can central banks' monetary policy be described by a linear (augmented) Taylor rule or by a nonlinear rule? J. Financ. Stabil. 7 (4), 228-246.

Catalán-Herrera, J., 2016. Foreign exchange market interventions under inflation targeting: the case of Guatemala. J. Int. Financ. Market. Inst. Money 42, 101-114.

Ca'Zorzi, M., Hahn, E., Sanchez, M., 2007. Exchange Rate Pass-through in Emerging Markets. European Central Bank. Working Paper 739.

Cerra, V., Saxena, S.C., 2000. Alternative Methods of Estimating Potential Output and the Output Gap-an Application to Sweden. International Monetary Fund.

Clarida, R., Gali, J., Gertler, M., 2000. Monetary policy rules and macroeconomic stability: evidence and some theory. Q. J. Econ. 115 (1), 147-180.

Clarida, R., Gali, J., Gertler, M., 1998. Monetary policy rules in practice: some international evidence. Eur. Econ. Rev. 42 (6), 1033-1067.

Côté, D., Kuszczak, J., Lam, J., Liu, Y., St-Amant, P., 2004. The performance and robustness of simple monetary policy rules in models of the Canadian economy. Can. J. Econ./Revue canadienne d'économique 37 (4), 978-998.

Cukierman, A., Gerlach, S., 2003. The inflation bias revisited: theory and some international evidence. Manch. Sch. 71 (5), 541-565.

Cukierman, A., Muscatelli, A., 2008. Nonlinear Taylor rules and asymmetric preferences in central banking: evidence from the United Kingdom and the United States. B E J. Macroecon. 8 (1)

Daude, C., Levy Yeyati, E., Nagengast, A.J., 2016. On the effectiveness of exchange rate interventions in emerging markets. J. Int. Money Finance 64, 239-261.
De la Torre, A., Yeyati, E.L., Pienknagura, S., 2013. Latin America's Deceleration and the Exchange Rate Buffer. The World Bank LAC Semi-Annual Report, October.

Debelle, G., 1999. Inflation Targeting and Output Stabilisation. Reserve Bank of Australia.

Dickey, D.A., Fuller, W.A., 1981. Likelihood ratio statistics for autoregressive time series with a unit root. Econometrica 1057-1072.

Dolado, J.J., Maria-Dolores, R., Naveira, B.M., 2000. Asymmetries in Monetary Policy Rules: Evidence for Four Central Banks (No. 2441), CEPR Discussion Papers.

Dolado, J.J., María-Dolores, R., Naveira, M., 2005. Are monetary-policy reaction functions asymmetric?: the role of nonlinearity in the Phillips curve. Eur. Econ. Rev. 49 (2), 485-503.

Edwards, S., 2007. The relationship between exchange rates and inflation targeting revisited. Central Bank. Anal. Econ. Pol. Book Ser. 11, 373-413.

Favero, C., Missale, A., Primiceri, P., 2000. Debt maturity and the reaction and performance of monetary policy. In: Chrystal, A. (Ed.), Debt Structure and Monetary Conditions. Macmillan, London.

Filosa, R., 2001. Monetary policy rules in some mature emerging economies. BIS pap. 8, 39-68.

Gagnon, J.E., Thrig, J., 2004. Monetary policy and exchange rate pass-through. Int. J. Finance Econ. 9 (4), 315-338.

Gali, J., Monacelli, T., 2005. Monetary policy and exchange rate volatility in a small open economy. Rev. Econ. Stud. 72 (3), 707-734.

Galimberti, J.K., Moura, M.L., 2013. Taylor rules and exchange rate predictability in emerging economies. J. Int. Money Finance 32, 1008-1031.

Garcia, C.J., Restrepo, J.E., Roger, S., 2011. How much should inflation targeters care about the exchange rate? J. Int. Money Finance 30 (7), 1590-1617.

Gemayel, E., Jahan, S., Peter, A., 2011. What Can Low-income Countries Expect from Adopting Inflation Targeting? IMF Working Papers, pp. 1-44.

Gerlach, S., Schnabel, G., 2000. The Taylor rule and interest rates in the EMU area. Econ. Lett. 67 (2), 165-171.

Ghatak, S., Moore, T., 2011. Monetary policy rules for transition economies: an empirical analysis. Rev. Dev. Econ. 15 (4), 714-728.

Ghosh, A.R., Ostry, J.D., Chamon, M., 2016. Two targets, two instruments: monetary and exchange rate policies in emerging market economies'. J. Int. Money Finance 60 172-196.

Goldberg, L.S., Campa, J.M., 2010. The sensitivity of the CPI to exchange rates: Distribution margins, imported inputs, and trade exposure. The Rev. Econ. Stat. 92 (2), 392-407.

Gonzalez-Astudillo, M., 2014. Identifying the Stance of Monetary Policy at the Zero Lower Bound: a Markov-switching Estimation Exploiting Monetary-fiscal Policy Interdependence. Federal Reserve Board Working Papers, 2014-2097, Washington, D.C..

Goodfriend, M., 1991. Interest rates and the conduct of monetary policy. In: CarnegieRochester Conference Series on Public Policy. Elsevier, pp. 7-30.

Granville, B., Mallick, S., 2010. Monetary Policy in Russia: identifying exchange rate shocks. Econ. Modell. 27 (1), 432-444.

Hansen, B., 1996. Inference when a nuisance parameter is not identified under the null hypothesis. Econometrica 64, 413-430.

Hansen, B., 2016. Graduate Econometrics Lecture Notes. Department of Economics, University of Wisconsin-Madison.

Hansen, L.P., 1982. Large sample properties of generalized method of moments estimators. Econometrica 1029-1054.

Hasanov, M., Omay, T., 2008. Monetary policy rules in practice: Re-examining the case of Turkey. Phys. Stat. Mech. Appl. 387 (16), 4309-4318

Hatipoglu, O., Alper, C.E., 2008. Estimating Central Bank Behavior in Emerging Markets: the Case of Turkey, (No. 7107). University Library of Munich, Germany.

Hodrick, R.J., Prescott, E.C., 1997. Postwar US business cycles: an empirical investigation. J. Money Credit Bank. 1-16.

Holtemöller, O., Mallick, S., 2016. Global food prices and monetary policy in an emerging market economy: the case of India. Asian J. Econ. 46, 56-70.

Jawadi, F., Mallick, S.K., Sousa, R.M., 2014. Nonlinear monetary policy reaction functions in large emerging economies: the case of Brazil and China. Appl. Econ. 46 (9), 973-984.

Judd, J.P., Rudebusch, G.D., 1998. Taylor's Rule and the Fed: 1970-1997. Economic Review-Federal Reserve Bank of San Francisco, pp. 3-16.

Klingelhöfer, J., Sun, R., 2018. China's regime-switching monetary policy. Econ. Modell. $68,32-40$.

Konuki, T., 2010. Estimating potential output and the output gap in Slovakia. E. Eur. Econ. 48 (2), 39-55.

Kwiatkowski, D., Phillips, P.C., Schmidt, P., Shin, Y., 1992. Testing the null hypothesis of stationarity against the alternative of a unit root: how sure are we that economic time series have a unit root? J. Econom. 54 (1), 159-178. 
Lee, J., Strazicich, M.C., 2003. Minimum Lagrange multiplier unit root test with two structural breaks. Rev. Econ. Stat. 85 (4), 1082-1089.

Leitemo, K., Söderström, U., 2005. Simple monetary policy rules and exchange rate uncertainty. J. Int. Money Finance 24 (3), 481-507.

Levin, A.T., Wieland, V., Williams, J., 1999. Robustness of simple monetary policy rules under model uncertainty. In: Taylor, J.B. (Ed.), Monetary Policy Rules. University of Chicago Press, pp. 263-318.

Lubik, T.A., Schorfheide, F., 2007. Do central banks respond to exchange rate movements? A structural investigation. J. Monetary Econ. 54 (4), 1069-1087.

Lumsdaine, R.L., Papell, D.H., 1997. Multiple trend breaks and the unit-root hypothesis. Rev. Econ. Stat. 79 (2), 212-218.

Mallick, S.K., Sousa, R.M., 2012. Real effects of monetary policy in large emerging economies. Macroecon. Dyn. 16 (S2), 190-212.

Martin, C., Milas, C., 2004. Modelling monetary policy: inflation targeting in practice. Economica 71 (282), 209-221.

Martin, C., Milas, C., 2013. Financial crises and monetary policy: evidence from the UK. J. Financ. Stabil. 9 (4), 654-661.

Masson, P.R., Savastano, M.A., Sharma, S., 1997. The Scope for Inflation Targeting in Developing Countries. IMF Working Papers, $1-0$.

McCallum, B.T., 1999. Issues in the design of monetary policy rules. Handb. Macroecon. $1,1483-1530$.

McCallum, B.T., Nelson, E., 1999. Nominal income targeting in an open-economy optimizing model. J. Monetary Econ. 43 (3), 553-578.

Miles, W., Schreyer, S., 2012. Is monetary policy non-linear in Indonesia, Korea, Malaysia, and Thailand? A quantile regression analysis. Asian Pac. Econ. Lit. 26 (2), 155-166.

Mishkin, F.S., 2007. The Dangers of Exchange-rate Pegging in Emerging Market Countries. Monetary Policy Strategy, p. 445.

Mohanty, M.S., 2013. Market Volatility and Foreign Exchange Intervention in EMEs: what Has Changed?-An Overview. An Overview (October 2013).BIS Paper, (73a).

Mohanty, M.S., Klau, M., 2005. Monetary Policy Rules in Emerging Market Economies: Issues and Evidence. Springer.

Moura, M.L., de Carvalho, A., 2010. What can Taylor rules say about monetary policy in Latin America? J. Macroecon. 32 (1), 392-404.

Murray, C.J., Nikolsko-Rzhevskyy, A., Papell, D.H., 2015. Markov switching and the taylor principle. Macroecon. Dyn. 19 (04), 913-930.

Nelson, C.R., Plosser, C.R., 1982. Trends and random walks in macroeconmic time series: some evidence and implications. J. Monetary Econ. 10 (2), 139-162.

Newey, W.K., West, K.D., 1994. Automatic lag selection in covariance matrix estimation. Rev. Econ. Stud. 61 (4), 631-653.

Obstfeld, M., Rogoff, K., 2000. New directions for stochastic open economy models. J. Int Econ. 50 (1), 117-153.

Orphanides, A., 2002. Activist Stabilization Policy and Inflation: the Taylor Rule in the 1970s. CFS Working Paper, No. 2002/15.

Orphanides, A., Van Norden, S., 2002. The unreliability of output-gap estimates in real time. Rev. Econ. Stat. 84 (4), 569-583.

Ostry, M.J.D., Ghosh, M.A.R., Chamon, M.M., 2012. Two Targets, Two Instruments: Monetary and Exchange Rate Policies in Emerging Market Economies. International Monetary Fund.

Perron, P., 1989. The great crash, the oil price shock, and the unit root hypothesis. Econometrica 1361-1401.

Phillips, P.C., Perron, P., 1988. Testing for a unit root in time series regression. Biometrika 75 (2), 335-346.

Ravn, M.O., Uhlig, H., 2002. On adjusting the Hodrick-Prescott filter for the frequency of observations. Rev. Econ. Stat. 84 (2), 371-376.
Robert-Nobay, A., Peel, D.A., 2003. Optimal discretionary monetary policy in a model of asymmetric central bank preferences. Econ. J. 113 (489), 657-665.

Rudebusch, G.D., 2002. Assessing nominal income rules for monetary policy with model and data uncertainty. Econ. J. 112 (479), 402-432.

Sargan, J.D., 1958. The estimation of economic relationships using instrumental variables. Econometrica 393-415.

Sarikaya, C., Ogunc, F., Ece, D., Kara, H., Ozlale, U., 2005. Estimating Output Gap for the Turkish Economy. Research and Monetary Policy Department, Central Bank of the Republic of Turkey.

Schmidt, P., Phillips, P.C., 1992. LM tests for a unit root in the presence of deterministic trends. Oxf. Bull. Econ. Stat. 54 (3), 257-287.

Shortland, A., Stasavage, D., 2004. What determines monetary policy in the Franc zone? Estimating a reaction function for the BCEAO. J. Afr. Econ. 13 (4), 518-535.

Shrestha, P.K., Semmler, W., 2015. Monetary policy and international reserves in emerging economies: theory and empirics. In: Finch, N. (Ed.), Emerging Markets and Sovereign Risk. Palgrave Macmillan, pp. 213-230.

Siegfried, J.J., 2010. Better Living through Economics. Harvard University Press.

Stuart, A., 1996. Simple monetary policy rules. Bank Engl. Q. 36 (3), 281-287.

Surico, P., 2007. The Fed's monetary policy rule and US inflation: the case of asymmetric preferences. J. Econ. Dynam. Contr. 31 (1), 305-324.

Svensson, L.E., 2000. Open-economy inflation targeting. J. Int. Econ. 50 (1), 155-183.

Svensson, L.E., 1997. Inflation forecast targeting: implementing and monitoring inflation targets. Eur. Econ. Rev. 41 (6), 1111-1146.

Svensson, L.E.O., 2003. What is wrong with Taylor rules? Using judgment in monetary policy through targeting rules. J. Econ. Lit. 41 (2), 426-477.

Svensson, L.E.O., 1999. Inflation targeting as a monetary policy rule. J. Monetary Econ. 43 (3), 607-654.

Taylor, J.B., 2013a. The effectiveness of central bank independence vs. policy rules. Bus. Econ. 48 (3), 155-162.

Taylor, J.B., 2013b. International monetary coordination and the great deviation. J. Pol. Model. 35 (3), 463-472.

Taylor, J.B., Nov, 1998. Monetary policy and the long boom. Federal Reserve Bank St. Louis Rev. 3-12.

Taylor, J.B., 2001. The role of the exchange rate in monetary-policy rules. Am. Econ. Rev. 91 (2), 263-267.

Taylor, J.B., 2000. Using monetary policy rules in emerging market economies. In: The 75th Anniversary Conference, "Stabilization and Monetary Policy: the International Experience". Bank of Mexico.

Taylor, J.B., 1999. The robustness and efficiency of monetary policy rules as guidelines for interest rate setting by the European Central Bank. J. Monetary Econ. 43 (3), 655-679.

Taylor, J.B., 1993. Discretion versus policy rules in practice. In: Carnegie-Rochester Conference Series on Public Policy. Elsevier, pp. 195-214.

Taylor, M.P., Davradakis, E., 2006. Interest rate setting and inflation targeting: evidence of a nonlinear Taylor rule for the United Kingdom. Stud. Nonlinear Dynam. Econom. 10 (4).

Tong, H., 1990. Non-linear Time Series: a Dynamical System Approach. Oxford University Press.

Woodford, M., 2001. The Taylor rule and optimal monetary policy. Am. Econ. Rev. 91 (2), 232-237.

Yilmazkuday, H., 2008. Structural breaks in monetary policy rules: evidence from transition countries. Emerg. Market. Finance Trade 44 (6), 87-97.

Zivot, E., Andrews, D.W.K., 1992. Further evidence on the great crash, the oil-price shock, and the unit-root hypothesis. J. Bus. Econ. Stat. 10, 251-270. 